\title{
AN ANALYSIS OF AFGHANISTAN'S RANGELANDS AND MANAGEMENT ISSUES FOR THE DEVELOPMENT OF POLICY AND STRATEGIES FOR SUSTAINABLE MANAGEMENT
}

by

Donald J. Bedunah, Ph.D.

Certified Range Management Consultant

For

Chemonics International, Inc.

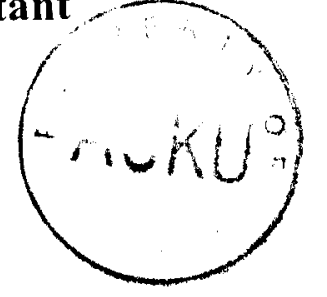

January 5, 2006

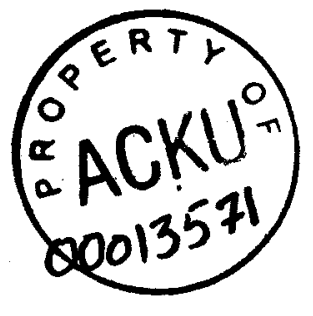




\section{TABLE OF CONTENTS}

ACKNOWLEDGEMENTS .............................................................................................ii

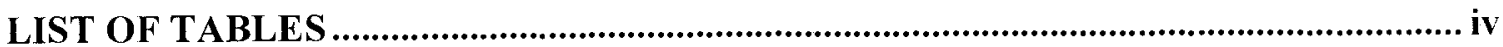

LIST OF APPENDICES ...................................................................................................... iv

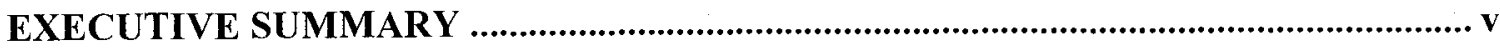

Task A. A review of Afghanistan rangeland management and livestock development documentation produced over the last 30 years by FAO....................................................... 1

Task A: Literature Cited ............................................................................................................... 4

Task B. Review recently approved natural resource management policies, including environmental protection..................................................................................................... 6

Task B: Literature Cited............................................................................................................. 9

Task C. An assessment of the scale, geographical distribution, and diversity of

Afghanistan's rangelands...................................................................................................... 1

Task C: Literature Cited............................................................................................................... 6

Task D. Categorization of rangeland according to species composition and productivity

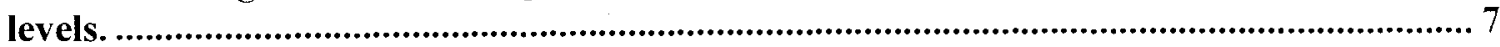

Task D: Literature Cited .............................................................................................................. 8

Task E. An indicative assessment of the carrying capacity of the different types of rangeland including the seasonal variations in carrying capacity....................................... 9

Task E: Literature Cited............................................................................................................ 17

TASK F: An Analysis of Current Rangeland Management Practices and User Rights and an Assessment of the Sustainability of Such Practices Relative to Rangeland Productivity Levels. ................................................................................................................. 19

Task F: Literature Cited ............................................................................................................... 22

Task G. Identification of key rangeland management issues and possible options for

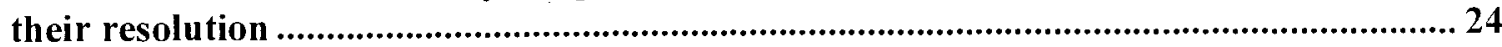

Task G: Literature Cited ................................................................................................................ 31

Task $H$. Rangeland policy and strategies for sustainable management. .............................33

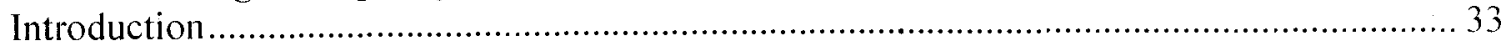

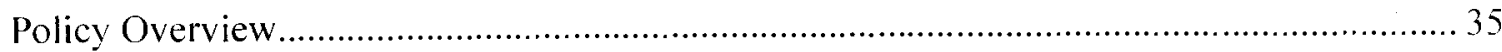

Strategy and Needs for Achieving Rangeland Sustainability ................................................... 36

Rangeland Inventory and Classification (including Land Suitability) ....................................... 37



Integrated Resource Management Planning …………………........................................... 39

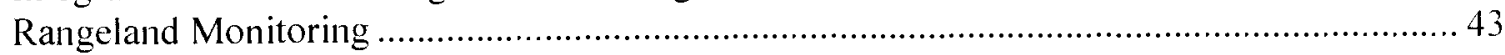

Monitoring by Pastoralists ............................................................................................. 43

Monitoring by the Department of Natural Resources............................................................. 44

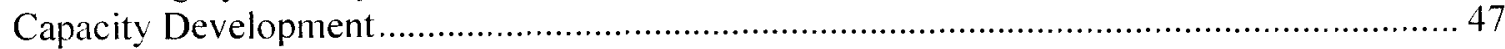

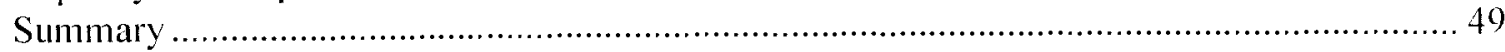

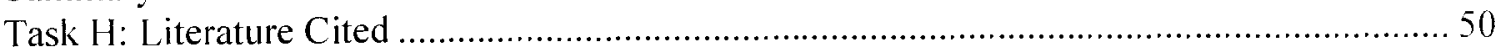

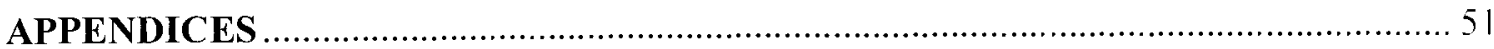




\section{ACKNOWLEDGEMENTS}

During my $31 / 2$ weeks in Kabul 1 met many people that have worked, and continue to work, on Afghan rangeland management and/or related issues. In many cases these individuals are cited in this report, but I would like to acknowledge a few individuals who were instrumental in providing support in Kabul. I express my sincere appreciation to Mr. Daniel Miller, U.S. Agency for International Development, for his support, interest, and knowledge of rangeland ecosystems. He was invaluable in providing direction and in discussions regarding rangeland issues. Likewise, Ms. Frauke de Weijer, an expert on kuchi issues, provided a great deal of information on the pastoralists and related rangeland issues. The conference "Conference on Pastoralists (kuchi)" developed by Ms. Weijer was an excellent introduction to problems and needs of the Afghan pastoral community. Dr. Liz Alden-Wiley provided indepth discussions of land tenure issues at the conference and she was gracious enough to discuss Afghan land tenure issues with me on a number of occasions. Mr. Khurin, director of Forestry and Range Management Department, and Mr. Anam, former director, provided assistance and their insights into natural resource issues and concerns. I thank Dr. Herschel Weeks for his help on policy issues and Drs. Euan Thomson, Tom Fattori and Mohammad Usman for their help and insights on Afghan agriculture issues. Lastly, this project would not have been possible without the support from the USAID RAMP initiative, Rebuilding Agricultural Markets Program (RAMP), and 1 thank USAID for their support. 


\section{LIST OF TABLES}

Table 1. A fghanistan land use (1993) (from Provincial Land Cover Atlas of Islamic State of A fghanistan, FAO/UNDP Project AFG/90/002 (1999) from Thieme, nd.).

Table 2. Livestock numbers of Afghanistan (from Bhattacharyya and others, 2004)................ 2

Table 3. The climatic types of Afghanistan (Khaurin, 1966 from Thieme, nd)....................... 3

Table 4. Geographic zones of Afghanistan (from Thieme , nd) .......................................... 3

Table 5. Productivity capacity and income from Agroforestry in Faryab Province, A fghanistan

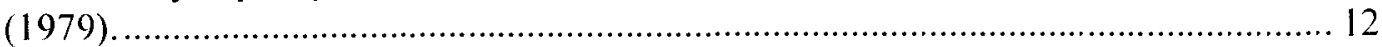

Table 6. Herbage yield estimates in Registan Desert (from Toderich andTsukatani, 2005)...... 13

Table 7. Carrying capacity estimates of Registan Desert (from Toderich andTsukatani, 2005)........ 14

Table 8. Resource management plan outline............................................................ 41

Table 9. A degradation classification of vegetation of a temperate mountain meadow ecological site*

Table 10. An example of a rangeland health evaluation summary form where a site is compared to a reference site (descriptors not shown).

\section{LIST OF APPENDICES}

Appendix 1. FAO archives, Afghanistan 1960-96

Appendix 2. FAO reports available from ACBAR ..................................................... 53

Appendix 3. Other citations noted from other sources that should be reviewed for inclusion in

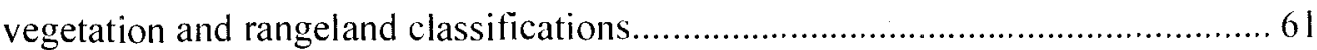

Appendix 4. Policy agenda from Asian Development Bank, 2003................................65

Appendix 5. Mean annual precipitation of Afghanistan (from Afghanistan Information Management Service (AIMS)(http://www.aims.org.af/)

Appendix 6. Climatic regions of A fghanistan (from Afghanistan Information Management Service (AIMS)(http://www.aims.org.af/) .............................................6. 67

Appendix 7. Soils of Afghanistan (from Sayer and van der Zon, 1981)........................... 68

Appendix 8.. Vegetation types of A fghanistan (source Sayer and van der Zon, 1981)............ 69

Appendix 9. Vegetation map of Afghanistan (FAO, 1980) ............................................. 72

Appendix 10. Vegetation classification of Afghanistan (source, Nedialkov, 1973), ............. 73

Appendix 11. Natural vegetation (potential) of Afghanistan (FAO. 1999) (from AIMs)......... 74

Appendix 12. Soils of A fghanistan (FAO, 1999 from Afghanistan Information Management Service (AIMS)(http://www.aims.org.af/)................................................ 75

Appendix 13. Forage Resources for Ghazni and Zaboul (from Casady, G.M. nd.). ................ 76

Appendix 14. Mechanisms to strengthen pastoralist's livelihoods and mechanisms for support of alternative livelihoods (modified from Weijer, 2005)................................. 77

Appendix 15. The Development of an Integrated Resource Management Plan......................... 78

Appendix 16. Resource Systems Analysis Approach (summary statement)....................... 80 


\section{EXECUTIVE SUMMARY}

The objective of this consultancy was to review information on Afghanistan's rangelands in order to develop rangeland policy consistent with other approved natural resource management policies and livestock development strategies. The consultancy included 8 tasks:

1. A review of A fghanistan rangeland management and livestock development documentation produced over the last 30 years.

2. A review of recently approved natural resource management policies, including environmental protection.

3. An assessment of the scale, geographical distribution and diversity of Afghanistan's rangelands.

4. Categorization of rangeland according to species composition and productivity levels.

5. An indicative assessment of the carrying capacity of the different types of rangeland including the seasonal variations in carrying capacity.

6. An analysis of current rangeland management practices and user rights and an assessment of the sustainability of such practices relative to rangeland productivity levels.

7. Identification of key rangeland management issues and possible options for their resolution.

8. Development of rangeland policy and strategies for sustainable management.

These tasks are presented as individual sections in this document with citations, tables, and/or appendices. This report was developed following a review of existing information, interviews with individuals involved in natural resource policy and management during my period in Afghanistan (November 14-December 4. 2005) and participation in the Conference on Pastoralists (kuchi) held in Kabul (November 15-17, 2005).

Rangelands, defined as uncultivated lands that supply a grazing or browsing resource to domestic and wild animals, are by far the major land type in Afghanistan comprising between 70 and $80 \%$ of the country. The sheer size and diversity of these rangelands is justification that they receive greater emphasis in future development and research by the Afghanistan government, as well as from international development and environmental organizations. Livestock grazing is one of the primary uses of these rangelands, but these rangelands also supply a number of products, including water, fuel woods, and wildlife as well as other products and values. Livestock have been critical to the economy of Afghanistan in providing products for domestic use and export. In the 1970s, Agriculture supplied approximately $50 \%$ of the Gross Domestic Product (GDP) and livestock supplied about $25 \%$ of the agriculture GDP. There is no 
doubt that extensive livestock production is of critical importance in maintaining the level of livestock production; yet, there is a dearth of sound information on Afghanistan's rangelands. Apparently, there has never been a large amount of rangeland information. Also, with more than two decades of conflict (and collapse of national, provincial and local forms of governance) some information was lost; and. in general natural resources have been exploited throughout this period.

The development of a rangeland policy must realize the value of rangelands to the national economy for producing not only animal products, but as watersheds, wildlife habitat (biodiversity), for carbon sequestration, and open space and aesthetic values. A rangeland policy must conserve (provide for sustainable uses) rangelands for future generations. Community based management must be stressed in the management of State or public rangelands. National rangeland policy must direct a national plan to categorize and understand rangeland ecosystems. This will include a classification of values (productivity, variability, products including forage, biodiversity, etc), a determination of the state of health of the rangelands (including desertification, degradation, watershed condition, etc.), and land suitability. In some instances rangeland use may stress animal production: whereas, in other areas rangeland use may stress wildlife values, watershed values, carbon sequestration or other values. Where rangelands are not producing at their potential there needs to be an assessment of the causes of degradation through monitoring and analysis and a catalogue of rehabilitation methods for the type of site and type of damage. All Ministries involved in natural resource management (for example MAAHF and MIRWE), and those involved with rural peoples and nomadic peoples (for example MRRD and MFTA), are stakeholders in rangeland policy and should participate in setting policies and strategies. However, it is apparent that the Department of Natural Resources (formerly Department of Forestry and Rangelands) should be the lead agency in directing rangeland policies and strategies.

The rangeland policy environment is complex because of interactions with other sectors of the economy and also because rangelands supply both extrinsic or economic values (example given, livestock) and intrinsic values (such as aesthetic values or clean air and water). In Afghanistan, the policy environment is made extremely difficult because of ambiguous land tenure claims, ethnic conflicts, rangeland degradation, droughts, and an increasing population 
with limited livelihood opportunities'. There is no doubt that the most critical problems regarding sustainable use of rangeland are conflicts in land tenure and access and a lack of institutional capacity for managing and understanding rangeland ecosystems. Other critical rangeland problems, some associated with land tenure/land access problems and often associated with each other, are inadequate knowledge of rangelands and rangeland values, rangeland degradation (including improper cultivation of rangelands and loss of fuels), frequency of droughts and procedures to rehabilitate rangelands. It is my opinion that livestock products as well as other rangeland products (wildlife, water, etc.) could be significantly improved with better rangeland and livestock management. In addition, improved management that ensured sustainable use of rangelands would also be more likely to conserve or support traditional lifestyles and cultures.

I have stressed five major programs or strategies to build a sound policy for sustainable rangeland management. These are: (1) Rangeland Inventory and Classification; (2) Drought Preparedness, (3) Integrated Natural Resource Management Planning; (4) Rangeland Monitoring; and (5) Capacity Development (education and training). All of the strategies are interrelated and should be directed by the Department of Natural Resources at national. provincial, district and village levels. It is at the community level where management actions will ensure productive use of rangelands and I have stressed the need for community based natural resource planning to begin immediately as "pilot projects". Of critical importance in developing community based plans is the identification of the community(s) in which the plan will be developed for and to plan within the social context of the community. This is especially critical in Afghanistan because of the land tenure/access and security issues. In proceeding with the development of strategies to provide for sound rangeland management programs there is an immediate need to improve capacity of the Department of Natural Resources through training and education. I suggest that this will require grants from development organizations and outside donors with the goal of environmental improvement of Afghanistan's natural resources. I propose that the pilot projects be developed to provide additional training (initial training should be short courses and/or workshops with long term training being associated with graduate education) for individuals within the Department of Natural Resources to facilitate the process of developing more sound resource management.

\footnotetext{
One issue that I did not address is poppy cultivation. There are certainly concerns regarding plowing of rangelands (which I did discuss but not associated with poppy cultivation) and land access that in some cases is likely associated with poppy cultivation, but l just refer to land tenure/land access concerns in general.
} 


\section{Task A. A review of Afghanistan rangeland management and livestock development documentation produced over the last 30 years by FAO.}

There have been a considerable number of Afghanistan development projects funded by FAO during the last 30 years. The earliest FAO projects cited were projects funded during the early 1960s. For FAO projects developed in the late 1990s there is documentation (proposals and/or reports) available in Afghanistan, but for many of the older projects documentation (reports) was not located in Afghanistan. A search of FAO web sites, other web sites, and various offices in Kabul located some information. A listing of FAO funded Afghan studies (archived) was found at www. fao.org/world/afghanistan/arch en.htm and this web site had over 67 titles (Appendix 1). The majority of the documents found at this site were proposals and only a few final reports were available. I was told numerous times that most of these reports were lost during the war years.

A source that listed a number of other documents dealing with FAO development programs and other rangeland development projects is the ACBAR Resource Center library. The ACBAR Resource Center library lists 122 titles (Appendix 2), but only one is specifically listed under the subject of range management ${ }^{2}$. Other related reports (numbers in parentheses) include livestock reports (6), nomads (1), general agriculture (15), land cover/land resources (2), forestry (4) and general ecology (2). There were three ecological classification systems in Dari:

1. Ecological classification of Afghanistan [Dari] / Sayed Amir Shah Hassanyar:

2. Ecology of Afghanistan [Dari] / Sayed Amir Shah Hassanyar (this document was listed under agroecology and may not be a general publication on ecology of Afghanistan): and,

3. Ecology of the central regions [Dari] / Sayed Amir Shah Hassanyar Sayed Noor Aga
Hashemi.

None of the Dari publications on ecological classification were found in Afghanistan, nor was the citation by Alpay on range management located. I have ordered the publications from ACBAR Resource Center (as well as others) and will add the information as a pdf scan when received. I will attempt to make a determination of the value of the Dari ecological

\footnotetext{
2 Alpay, O. N. 1974. Range management and animal husbandry practices in Afghanistan for demonstration and training in forest and range improvement project.
} 
classifications by using scientific names, but someone with knowledge of Dari should translate the information for future use. Nedialkov (1973) also provides a natural vegetation classification of 6 formations and 13 Etages (subformations/associations) (in French) and a vegetation map similar to FAO natural vegetation map (see Appendices 9-11 discussed under the section Task C, "An assessment of the scale, geographical distribution and diversity of A fghanistan"s rangelands").

The lack of FAO titles having a subject of "range management" does not mean that other reports do not mention rangelands or range management aspects. For example, Petocz and Larsson (1977) (see Appendix 2) in "Ecological Reconnaissance of Western Nuristan with Recommendations for Management" provides a description of ecological communities (although no complete species lists or coverage or production values). Petocz (1978) provides a table (pg. 10-11) of plant composition of 5 alpine habitat types in the Pamir region and also show traditional pastoral territories. Sayer and van der Zon (1981) also refer to rangelands, rangeland management and values and problems in their report on national parks and wildlife management in Afghanistan. They also provide a general review of the geography, ecology and biology of Afghanistan including soils and vegetation. This is an excellent overview of many aspects of natural resources and although the document is over 20 years old it is still very relevant.

The following paragraphs include a major portion of the section on rangelands from the Sayer and van der Zon (1981) report to illustrate that type of information presented in their report.

"The rangelands are essential for nomads and for a large part of the settled population who derive their income from animal rearing and employment in the livestork industry. In view of the importance of these areas, it is astonishing that so little is known about their ecology or productive potential. The proportion of the domestic and international aid effort dedicated to range studies or management is very small. The few specialists who have knowledge of range conditions in Afghanistan are unanimous in their opinion that present mismanagement, and especially overgrazing, is causing a deterioration in range conditions and therefore in productive potential. Opinions vary on the extent to which this deterioration may be irreversible.

The Afghan rangelands can be divided into three categories; the winter $(16,210,000$ ha); the spring and autumn ( $16,030,000 \mathrm{ha})$ and the summer $(22,460,000 \mathrm{ha})$ pastures. The relatively small extent of the Artemisia steppes which provide winter pasture in the south and west limits the number of livestock. These areas are very sensitive to overgrazing. The Soviet border prevents the nomads reaching large parts of their traditional winter range. 
The most compelling evidence for the disequilibrium between stock and pasture comes from the pattern of fluctuations of livestock numbers. The population, especially sheep, tends to increase rapidly in years of average or above average rainfall. Then, when the inevitable dry years come, the numbers fall dramatically. This happened last in 1972/73 when $40 \%$ of the sheep did not survive the winter. The sheep population is now approaching a maximum and heavy mortality will occur in the next year when rainfall is significantly below average. Since the long-term tendency is for range condition to deteriorate, successive drops in livestock numbers may be expected to be more and more severe.

The Veterinary Services Department considers that the carrying capacity in the Afghan context is that number of animals which can be brought through the winter with a loss of no more than $10 \%$ body weight. This implies that winter grazing is at present the factor limiting stock numbers. It also suggests that there is a relative superabundance of summer grazing. This is not, however, the whole story as winter survival and weight loss are influenced by the condition of animals at the end of the summer. A present trend which it has been suggested may be of great long-term significance is that the proliferation of irrigation schemes and the growth of dry farming in winter grazing areas is forcing herdsmen to forsake winter pastures earlier than normal. The sheep therefore return to the hill pastures early in the spring when the seedlings of shrubs, which germinate before the first flush of grass, are the only available fodder. These shrubs are a very important component of the vegetation cover, and are especially valuable for protecting and stabilizing the soil surface. They are aromatic and later in the season they are not very palatable to grazing animals as alternative food is available. These shrubs are also collected on an enormous scale for fuel. They are therefore being replaced by annual herbs and grasses which give less protection to the soil. Too early grazing of these grasses and sedges may weaken the plants to the extent that they are unable to set seed and may even die. Any change in the relative importance of shrubs, forbs and grasses is likely to have repercussions on the water balance and soil erosion characteristics of the range as well as on its productivity and therefore deserves careful study."

Sayer and van der Zon (1981) suggest a number of range management programs to provide for better natural resource management. They also utilize other FAO reports to provide numerous maps and figures including precipitation zones, natural vegetation, forest cover, rivers and wetlands, soils, mammal distribution, and priority conservation areas as well as other maps.

There are also numerous other citations that may be of value for specific projects or as review articles (Appendix 3). However, it is apparent that there is a dearth of ecological and range management information for the development of natural resource management plans for specific areas (a lack of ecological site information having plant community information, productivity, variability in production, different states, etc.). There are currently a number of 
broad classifications that could be used in regional ecological classifications and as the initial step in developing more site specific information. FAO also developed land cover maps that are of general use and apparently there are plans to upgrade land cover maps at a scale of 1:250,000 and topographic maps at $1: 50,000^{3}$.

Since the late 1990s there have been a number of other relevant FAO publications regarding natural resources/agriculture in Afghanistan (for example, FAO, 1997, 1998, 2000. 2002). Thieme (nd) provides an overview of Afghanistan's rangelands and forage resources and Thieme (2003) discusses livestock development for food security. Favre (2003) provides an account of the problems of rangeland cultivation in Dasht-E Laili and how this is impacting rangelands and nomadic herders using the area. There was also the livestock count published in 1998 and a number of agriculture and animal health and livestock reports (FAO, 1998).

The FAO information and other reports do provide a sound overview of rangelands of Afghanistan and summarize many of the values and problems related to these rangelands. However, it is clear that much of the information is general and there is a strong need to develop more specific information for management of A fghan rangelands. There is little or no information in these publications on methods for analyzing or monitoring rangelands, determining degradation or methods for rehabilitation of different types of rangelands, developing specific values of rangeland systems (including productivity, seasonal variation, etc.) or even general land suitability classes.

\section{Task A: Literature Cited}

FAO (Food and Agriculture Organization). 1997. Afghanistan Agricultural Strategy: Promotion of Agricultural Rehabilitation and Development Programmes for Afghanistan. Project No. TC:TCP/AFG/4552. FAO, Rome, Italy.

FAO (Food and Agriculture Organization). 1998. Summary of Livestock Headcount 1997/98. Project AFG/96/007 Livestock Development for Food Security in Afghanistan. FAO. Islamabad, Pakistan.

\footnotetext{
See project document for Essential Mapping Project, Afghanistan Geodesy and Cartography Head Office, (AGCHO)]; Public Administration \& Economic Management. 3 Ist December 2003. AFG/04838
} 
FAO (Food and Agriculture Organization). 2000. Final Report (11/9/1994 . 30/6/2000). Animal Health and Livestock Production Programme in A fghanistan. (Project No. FAO/AFG/93/004 and FAO/AFG/96/007). FAO, Rome. Italy.

FAO (Food and Agriculture Organization). 2002. Annual Report 2001. Animal Health Component. Food Security through Crop Production and Livestock Development. (Project No. FAO/AFG/00/015). FAO, Islamabad, Pakistan.

Favre, Raphy. 2003. Grazing Land Encroachment Joint Helicopter Mission to Dasht-E Laili, 25-27 March 2003. FAO FAAHM/AFGHANISTAN OSRO/AFG/1 II/USA. 23rd July 2003, $20 \mathrm{p}$.

Larsson. J.Y. and C.C. Shank. 1977. A strategy for the establishment and development of Bande Amir National Park. FAO. www.afghanresources.org

Maletta. Hector and Raphy Favre. Nd. Agriculture and food production in post-war Afghanistan a report on the winter agricultural survey 2002-2003.

ftp://ftp.fao.org/docrep/fao/007/ae407e/ae407e02.pdf

Nedialkov, S. 1973. Etude sur la classification ecologique de la vegetation legneus natural en Afghanistan. UNDP/FAO/67.

Petocz, R.G. 1978. Report on the Afghan Pamir, Part I: Ecological reconnaissance. UNDP/FAO. FO:DP/AFG/74/0I6. Field Document No. 5. 54p. Kabul. Www.afghanresources.org

Petocz. R.G. and J.Y. Larsson. 1977. Ecological reconnaissance of western Nuristan with recommendations for management. UNDP/FAO. FO:DF/AFG/74/016 Field Document No. 9. Kabul. www.afghanresources.org

Sayer, J.A. and A.P.M. van der Zon. 198I. Afghanistan: National parks and wildlife management. A contribution to a conservation strategy. Volume I. FO: DP/AFG/78/007. Technical Report, Vol. I.

Thieme, O. 1996. Afghanistan - Promotion of Agricultural Rehabilitation and Development Programmes: Livestock Production. Project TCP/AFG/4552. FAO, Rome, Italy.

Thieme, Olaf nd. Afghanistan, Country Pasture/forage resource profiles. Food and Agriculture Organization, Rome. http:/Www.fao.org/ag/AGP/AGPC/doc/Counprof/afghan/afghan.htm (October 30, 2005).

Thieme, O. 2003. Livestock development for food security: Food security through sustainable crop production and livestock development. Final Technical Report on Livestock \& Fodder Production Activities, September 1997 - December 2002. FAO (Food and Agriculture Organization of the United Nations). Rome. Italy and UNDP (United Nations Development Program), New York, USA. 


\section{Task B. Review recently approved natural resource management policies, including environmental protection.}

Policies are currently being drafted regarding national resource management and protection of natural resources, but apparently most are in the initial stages of preparation. In the Ministry of Agriculture, Animal Husbandry, and Food (MAAHF) the development of a Master Plan is currently proceeding, but at the time of this consultancy was still in draft form. One of the more comprehensive natural resource acts that I reviewed was the "Environmental Management Act"4. This act is currently in draft form, but provides a number of provisions in regards to rangeland systems. Included in the draft are chapters on Integrated Environmental Management. Integrated Pollution Control, Water Resource Conservation and Management. Biodiversity and Natural Resource Conservation and Management, Environmental Information, and Education and Training Research to name the more relevant chapters. This act has numerous references to rangelands. sustainable use of natural resources, integrated watershed management, and many other sections that will provide for direction in rangeland management if the Act becomes law. It also specifies criteria for integrating conservation into development planning (Article 25) that appears to be somewhat in conflict with Asian Development Bank (ADB) (2005) recommendations on setting limits on numbers of grazing animals (see next paragraph).

The Asian Development Bank (2003) provides a summary of policy needs related to the agriculture sector, including natural resources (Appendix 4). It was difficult to determine how far these recommendations have moved as policy, but there is no doubt that they are needed and several have direct application to rangeland issues. Asian Development Bank (2005) also provides numerous recommendations on policies related to land use, land tenure/access and management. In this document there is a procedure for limiting numbers of grazing animals on public or government land.

"Limits on the number of grazing animals on Government and public lands should be set by local communities as part of the agreed land management regime. If it is seen by the relevant land use planning and regulating authority to be environmentally necessary or desirable to reduce the amount of, or completely prohibit, grazing or any other land use, on all land in any particular area, including

\footnotetext{
4 “Environmental Management Act, Draft 4.2. 17 April 2005. Islamic Republic of A fghanistan. 49 p.
} 
privately owned land there should be a system under a new Land Code which gives power to land use planning and regulating authorities, after adequate public consultation, to issue notices restricting or prohibiting grazing or any other type of land use. The Land Code should provide for the payment of compensation for such restrictions or prohibitions. either by way of the relevant authority or the Government being obliged to purchase, at full current market value, any land over which such restrictions or prohibitions have been placed or by the payment of independently assessed monetary compensation or by granting other land elsewhere. Such land could be granted either as complete replacement for the restricted or prohibited land or as a supplement to its permitted level of production."

This procedure maybe in conflict with Article 25 of the Draft Environmental Management Act where the responsibility for natural resource plans "must be approved by Director General of the responsible ministry". Also, the suggested procedure on setting limits on grazing animals does not appear to consider other resource values that may be impacted by grazing animals as it appears to only consider the wishes of the "local community". This policy needs considerable discussion as local communities should be involved in planning, but should not necessarily set the limits on number of grazing animals on public or government lands. On public and government lands grazing levels should be set in discussions with natural resource managers (Department of Natural Resources) and the users of those lands as they work together to develop a plan for use of those grazing lands. Natural resource values should be considered, especially watershed and wildlife values, as well as sustainable use of fuels and grazing lands. Local communities and natural resource managers should monitor the impacts of grazing on resources to determine if grazing levels are sustainable.

Currently, the MAAHF is restructuring. During my consultancy 1 found it difficult to determine the "Mission" of various departments. The document "Policy, Monitoring and Evaluation and Planning in MAAHF" (2005a) was obtained from Dr. Usman, Senior Policy and Planning Advisor. He stated this draft document is to improve the policy and planning in MAAHF. This document states that the MAAHF fully endorsed the Civil Service Commission guidelines for restructuring to more of a "lean and technical" institution.

\footnotetext{
"It is unknown if the role of government in this paragraph is associated with the statement "with the agreed land management regine". Perhaps initial stocking levels and consideration of other resource values is associated with this statement; although, it is certainly does not appear to and is certainly not stressed.
} 
This led to a joint agreement with the Civil Service Administration the MAAHF would have six general departments:

1. Livestock and Plant Technical Services (LPTS)

2. Policy Economic Analysis and Planning (PEAP)

3. Natural Resource Management (NRM)

4. Food, Agro-Industry and Market Development (FAIMD)

5. Quality Control (QC)

6. Finance and Administration (FA)

The draft states (pg. 4) that: "Of the six departments, the general departments of Food, Agro-Industry and Market, and the Quality Control are new additions to the Ministry where FAIMD was part of the dissolved Ministry of Light Industries and joint Ministry of Agriculture. Quality Control is a newly created department. It is also anticipated that an Irrigation department would be established under the general department of Natural Resource Management, the size and scope of this department depends on what would be the responsibility of the Ministry of Energy and Water in the irrigation activities".

Under the new organization, the Policy Economic Analysis and Planning (PEAP) Department would have "a pivotal role in designing appropriate strategies, and identifying priorities; formulating policy advice based on proper analysis and accurate data; conducting prospective studies in crop production, trade, price and marketing; monitoring and evaluation the projects and programs; and establishing liaison and strong bond with donors, sister ministries serving the agriculture sector" (p. 5). Under the new organization, PEAP would consist of six divisions:

1. Policy and Analysis

2. Planning, Program and Project Development

3. Monitoring and Evaluation

4. Statistics and Agricultural Market Information

5. Foreign Affairs

6. Legislation Review and Analysis.

It is apparent that the main reason for the further development of the PEAP department is to create an enabling capacity to formulate appropriate strategy, policy, and position papers in the Ministry. It is difficult to see how this department will use the expertise (or future expertise) of other departments to build appropriate position papers, policy, and strategy.

In summary, it was difficult in my consultancy to identify new "approved environmental policy" and therefore I have discussed the draft Environmental Act (17 April 2005). discussion 
policy papers by ADB, and policy changes in MAAHF. The rangelands of A fohanistan are critical for not only livestock production. but as habitat for wildlife, carbon sequestration, watersheds, aesthetic values, production of fuel woods and medicinal plants. Extensive livestock systems will produce greater product values (livestock products, wildlife, fuels, water, etc.) with policies, technologies and management systems adapted for their environments and socioeconomic and cultural systems. Policies must provide incentives for sustainable natural resource management which must include secure property rights or access to key resources. It is necessary that marketing and pricing policies are adopted that provide for efficiency and better returns to livestock producers, especially the poor. On-going discussions appear to be working to develop these policies. I am concerned that the ADB (2005) suggestions, and similar statements in MAAHF (2005b), for policy/strategies on setting animal numbers provides too much control by local communities and not enough control (or at least direct facilitation) by professional resource managers. The setting of stocking levels on public or government lands needs to be set with all parties involved and with consideration of all resource values (although certainly there needs to be policy that allows certain uses and/or values to be emphasized for particular areas or conditions).

\section{Task B: Literature Cited}

Asian Development Bank. 2003. Rebuilding Afghanistan`s Agriculture Sector. Manila, Philippines, ISBN: 97I-561-493-0, Publication Stock No. 040903, 40 p. http:/community.eldis.org/webx?233@798.XXDBa7B3hJF.0@.ee9c405!enclosure-ee9c40 6 November 19, 2005

Asian Development Bank. 2004. Summary Report: National Programme Framework for Community Forestry and Range Management. (TA:3874-AFG), Component IB-2. Kabul, December 2004.

Asian Development Bank. 2005. Capacity Building for Policy Reform Land Policy and Its Implementation in Afghanistan: A discussion draft. TA: 4334-AFG. July.

MAAHF (Ministry of Agriculture, Animal Husbandry, and Food). 2005a. Policy, Monitoring and Evaluation and Planning in MAAHF”. Draft document, November, 2005. Kabul.

MAAHF (Ministry of Agriculture, Animal Husbandry, and Food). 2005 (November). Master plan for agriculture, animal husbandry and food. Kabul, Afghanistan. 389 p.

Islamic Republic of Afghanistan. Environmental Management Act, Draft 4.2. 17 April 2005. $49 \mathrm{p}$. 
there are many difficulties in determining the carrying capacity of an area. Behnke and Scoones (1993) provided a summary of many of the problems in determining carrying capacity:

"Both the precision and utility of evaluating feed supply-demand are, however, open to doubt. With respect to the precision with which estimates can be derived there is opportunity for significant error at almost every step in the calculation: proper use factor is at best a little more than an educated guess, estimation of the amount and kind of forage needed by an animal is not as straightforward as it seems, especially when several herd species exist: estimates of forage production have low precision, and carrying capacity assessment assumes fixed boundaries, but mobility of stock means that these assessments are artificial. On the other hand, it is in practice very difficult to assess carrying capacity in systems where spatially disparate resources are used at different stages of a flexible transhumant cycle."

This is not to say that there is not a need to define the number of grazing herbivores that are sustainable, but obtaining a reliable measure of carrying capacity according to western definition will be difficult. The traditional Kuchi system based on mobility and flexibility is well-adapted to conditions within Afghanistan. but this production system is not easily translated to a set carrying capacity of a defined land area. The high variability in precipitation spatially and temporally will also result in a need for "flexible" stocking rates rather than set stocking rates or carrying capacities.

Carrying capacity is generally estimated by determining forage/browse available per unit of land based, estimating a "proper use factor" to ensure plant health, and on the amount of forage needed by an "average animal unit" such as a sheep unit or cow unit which is based on animal weight and daily average forage consumption (generally $2 \%$ for ruminants and $3 \%$ for non-ruminant ungulates) to determine an initial stocking rate. As stated previously, carrying capacity estimates should also consider other attributes such as topography and water distribution. Obviously, there is "room" for error in all of these calculations and carrying capacity estimates based upon a one-point-in-time rangeland inventories do not produce results of sufficient accuracy to be the only basis for adjusting animal numbers on specific management units. Carrying capacity should instead be based on impacts of historical and current stocking rates, grazing management, and weather, and as such, be flexible or adaptable. Adjustments in carrying capacity should be made through monitoring over time to ensure progress toward desired resource conditions. Monitoring of rangeland condition to determine if management 
objectives are being met is an essential part of any rangeland resource policy. I suggest another sign that livestock numbers are too high is when conflict occur regularly between pastoralists grazing livestock in the same area (communal or government lands). Conflicts maybe associated with animal numbers being too high for the forage/browse resource, a lack of water to achieve proper animal distribution, problems in management of animals (conflicts regarding season of use, rotation of animals, wrong type of livestock for vegetation type, etc.), or drought conditions. Sound grazing management and land use plans are critical to reduce conflicts.

\section{Review of Carrying Capacity of Different Rangelands in Afghanistan}

Little information was found concerning carrying capacity of different types of Afghan rangelands and I conclude that this information did not exist in the past, except on a limited basis. I base my conclusion on interviews with several individuals (Professor Naseri. Chair of Department of Forestry and Natural Resource, Faculty of Agriculture, Kabul University; Mr. Alain de Bures, Technical Advisor, MADERA; Mr. Bakhtani, Department of Forestry and Natural Resources; Mr. Anam, former director of Forestry and Range Management Department, MAAH; Mr. Khurin, current director of Forestry and Range Management Department,

MAAHF). I did locate some information (for example Bakhtani, 1979 and Bakhtani. 1981 from Bakhtani, 2004) that suggest productivity measurements, but in a meeting with Mr. Bakhtani (November 24, 2005) he informed me that the carrying capacity was estimated fiom the animals that were grazing the area. He also said that the plant species information was of a very general nature. It is apparent that an analysis of land use was done in the study by Mr. Bakhtani (see Table 5) and that he did recognize a need for analysis of grazing capacity for these systems.

There have also been other limited studies on carrying capacity such as McArthur and others (1979) that report carrying capacity for three areas near Herat. Carrying capacities in the three areas were 0.8 to 1.32 ha/ewe equivalent (stocking rates 0.95 ha to 3.03 ha/ewe), but they commented that because of the great variability in climate the stocking rates were likely high for dry years and would result in large losses of stock. McArthur and others (1979) based their carrying capacities on a $60 \%$ utilization rate and apparently did not consider fuel use by the nomads which has been found to be quite significant (see below).

Casimir and others (1980) reported a stocking rate of 0.4 ewe equivalents/ha for Dasht-e Shoraw near Herat. The annual production was $450 \mathrm{~kg} / \mathrm{ha}$ and precipitation during that season 
was $170 \mathrm{~mm}$. They also reported that a household of 5 used $12 \mathrm{~kg} /$ day of fuel (brush) during the winter and during the season of intensive milk processing. During the remainder of the year they estimated fuel use of $7 \mathrm{~kg} /$ day. They also reported on problems with the non-equilibrium conditions of western Afghanistan. Volk (1972, from Qi and others, 1n press) provides estimates of average annual production between 800 to $2750 \mathrm{~kg} / \mathrm{ha}$ for sites in 4 provinces. As this publication was not found (not an English publication) I do not know if Volk discussed carrying capacity, but the estimates do provide a means for estimating carrying capacity for those areas.

Table 5. Productivity capacity and income from Agroforestry in Faryab Province, Afghanistan (1979).

\begin{tabular}{|l|c|c|c|c|}
\hline Production and returns & Mal char & Lalmi - Kari & Paliz - Kari & Sholi - Pista \\
\hline Grazing capacity (sheep/ha) & 10 & 1 & 10 & 10 \\
\hline Incomes \$/ha & 50 & 5 & 50 & 50 \\
\hline Fodder ton/ha & NO & 0.7 & NO & 0.3 \\
\hline Incomes \$/ha & NO & 42 & NO & 18 \\
\hline Grain yields ton/ha & NO & 0.85 & NO & NO \\
\hline Incomes \$/ha & NO & 85 & NO & NO \\
\hline Fruit and nut ton/ha & NO & NO & 3 & 0.1 \\
\hline Incomes \$/ha & NO & NO & 120 & 400 \\
\hline Medicinal crop ton/ha & NO & NO & NO & Yes \\
\hline Incomes \$/ha & NO & NO & NO & 10 \\
\hline Total income \$/ha & 50 & 132 & 170 & 478 \\
\hline
\end{tabular}

The former Veterinary Service Department considered carrying capacity as the number of animals that could be brought through winter with no more than a $10 \%$ weight loss (see Sayer and van der Zon, 1981). However, 1 did not locate any information stating that the Veterinary Service Department had classified rangeland types using this definition. Certainly other aspects (for example, summer conditions and management of animals) would also influence this carrying capacity estimate.

Toderich and Tsukatani (2005) provide a discussion of carrying capacity of the Registan Desert in Helmand and Kandahar Provinces. They estimated herbage yields from $80 \mathrm{~kg} / \mathrm{hat}$ to $800 \mathrm{~kg} / \mathrm{ha}$ associated with different precipitation zones and range conditions with an average production value of $500 \mathrm{~kg} / \mathrm{ha}$. They also estimated carrying capacity by precipitation zone, range condition and for seasonal and annual carrying capacity. Carrying capacity varied from 
$5.1 \mathrm{ha} / 1 \mathrm{LU}^{7}$ to 82 ha on a yearly basis. However, they state that carrying capacity is more determined by the length of the dry period rather than the number of animals.

Table 6. Herbage yield estimates in Registan Desert (from Toderich andTsukatani, 2005).

\begin{tabular}{|c|c|c|}
\hline Annual Precipitation $(\mathbf{m} \mathbf{m})$ & Range Condition & Estimated Yield (kg/ha) \\
\hline \multirow{3}{*}{100} & Poor & 80 \\
\cline { 2 - 3 } & Fair & 160 \\
\cline { 2 - 3 } & Good & 270 \\
\hline \multirow{3}{*}{150} & Poor & 120 \\
\cline { 2 - 3 } & Fair & 240 \\
\cline { 2 - 3 } & Good & 400 \\
\hline \multirow{3}{*}{200} & Poor & 160 \\
\cline { 2 - 3 } & Fair & 320 \\
\cline { 2 - 3 } & Good & 530 \\
\hline \multirow{2}{*}{250} & Poor & 200 \\
\cline { 2 - 3 } & Fair & 400 \\
\hline $300(\max )$ & Good & 660 \\
\hline
\end{tabular}

1 located two studies using satellite imagery for estimating rangeland vegetation attributes. Casady (no date) provides landscape estimates of productivity and estimated stocking rates for Ghazni and Zabul Provinces using satellite based estimates of the Normalized Difference Vegetation Index (NDVI) (Appendix 13). In this study there were poor correlations between NDV1 and vegetation production (highest $R^{2}=0.084$ ). This was attributed to a number of problems in timing of data streams and with ground measurements. Qi and others (In press) used satellite imagery to estimate vegetative cover. grass height, and total biomass in Afghanistan using an advanced vegetation index (EVI) and a senescent vegetation index (NDSVI) and also compared vegetation cover and biomass between 1992 and 2002 using AVHRR and MODIS imagery. They report strong correlations between sensors (Landsat $\mathrm{ETM}+$ ) and MODIS (Moderate Resolution lmaging Spectrometer), but had limited field data to correlate with ground measurements. They did show a reduction in vegetation cover and biomass between the 1992 and 2002 which was attributed to drought in the late 1990s and land use changes.

\footnotetext{
ILU was equivalent to $7.5 \mathrm{~kg}$ of dry matter use/day.
} 
Remotely sensed information will continue to provide landscape or "regional" estimates of productivity, land cover, and land cover change. This information can provide policy-makers with information on seasonal variation as well as annual variation (including use in drought warning systems as will be discussed in recommendations), but these estimates may have a limited role in determining carrying capacity or current stocking rates for particular subwatershed planning units or sub-districts, especially in mountainous areas where topographic variation is high. It is apparent that basic information on rangeland site productivity, species composition, and cover values is lacking. This type of information would assist those researchers using remote sensed data to estimate productivity to determine if their estimates were "reasonable" for Afghanistan.

Table 7. Carrying capacity estimates of Registan Desert (from Toderich andTsukatani, 2005).

\begin{tabular}{|c|c|c|c|}
\hline \multirow{2}{*}{$\begin{array}{c}\text { Annual } \\
\text { Rainfall (mm) }\end{array}$} & $\begin{array}{c}\text { Range } \\
\text { Condition }\end{array}$ & \multicolumn{2}{|c|}{ Hectares Required /ILU } \\
\cline { 2 - 4 } & All-season range & Seasonal range \\
\hline \multirow{3}{*}{50} & Poor & 82.0 & 328.0 \\
\cline { 2 - 4 } & Fair & 36.5 & 146.0 \\
\cline { 2 - 4 } & Good & 20.8 & 83.0 \\
\hline \multirow{3}{*}{15} & Poor & 54.5 & 218.0 \\
\cline { 2 - 4 } & Fair & 24.3 & 97.0 \\
\cline { 2 - 4 } & Good & 13.5 & 54.0 \\
\hline \multirow{3}{*}{100} & Poor & 40.9 & 163.6 \\
\cline { 2 - 4 } & Fair & 18.2 & 72.8 \\
\cline { 2 - 4 } & Good & 10.1 & 40.4 \\
\hline \multirow{3}{*}{200} & Poor & 27.2 & 108.8 \\
\cline { 2 - 4 } & Fair & 12.2 & 48.8 \\
\cline { 2 - 4 } & Good & 6.8 & 27.2 \\
\hline & Poor & 20.4 & 31.6 \\
\cline { 2 - 4 } & Fair & 9.1 & 20.4 \\
\hline
\end{tabular}

"The "average" animal (0.2 lLU) consumes $1.5 \mathrm{~kg}$ diy weight per day. Carrying capacity of seasonal range roughly estimated at one-fourth that of all-season range.

\section{Summary and Recommendations}

There is little specific information regarding rangeland productivity (including annual and seasonal variation) or carrying capacity for Afghanistan's rangelands. There is no doubt the majority of Afghanistan's rangelands are dominated by non-equilibrium conditions where there is great variability in forage production both spatially and temporally. Carrying capacity 
estimates should be used as more of an abstraction rather than a set number and stocking rates varied with conditions. In these environments drought will always be a significant factor in impacting productivity levels and animal numbers. However, in order to determine grazing prescriptions resource managers need to be able to define the variation in productivity levels and provide estimates of stocking rates for different vegetation types. As such, I do not believe that the controversy regarding establishing a "set" carrying capacity should be considered a reason to ignore animal effects. There will be a level of stocking which will result in "overgrazing" that will create a condition where a "level of acceptable change" is exceeded. The forage requirements of livestock must be balanced with the forage supply of the areas used for grazing and must consider the spatial and temporal variability in vegetation production. Sheehy and others (1991) stress that to realize the economic advantage of using animals to harvest forage requires that a balance be maintained between the requirements of plants and the requirements of animals using those plants. They state that there has been a long history of ignorance or indifference to this principle, resulting in the ecological deterioration of grazing resources. Controlled grazing or "prescribed grazing" (number, duration and timing of grazing) can be used to meet land management objectives. Prescribed grazing is defined as the controlled harvest of vegetation with grazing or browsing animals managed with the intent to achieve specified objectives and considers the economics of livestock production. Prescribed grazing can be applied as part of an integrated natural resource plan to address identified resource concerns or to accomplish one or more of the following purposes:

- Promote the health and vigor of selected plant(s) to be managed, and to maintain stable and desired plant communities.

- Improve or maintain animal health and productivity (domestic or wildlife) by providing sufficient food, cover and shelter for animals to be managed.

- Maintain or improve surface and groundwater quality and/or quantity for beneficial uses and/or hydrologic function, according to state water quality standards.

- Maintain or improve soil condition for resource sustainability, through the maintenance and enhancement of upland and riparian/wetland plant communities.

- Promote human economic stability through grazing land sustainability and management.

In considering livestock numbers animals should be managed in a manner to improve and/or maintain animal health and performance, and to reduce or prevent spread of disease, parasites, and contact with harmful insects. Grazing should be applied to meet the production 
requirements of the kind and/or class of animal, and to ensure proper density and structure of plant communities to meet cover and shelter requirements.

Where watershed concerns are great managers may prescribe or manipulate grazing intensity, frequency, duration, and season to:

- Maintain or restore riparian and upland vegetation,

- Maintain enough vegetation cover to prevent accelerated soil erosion by wind and water,

- Protect stream banks from erosion caused by management.

- Minimize the delivery of fecal material to water bodies,

- Promote ecologically stable and economically viable plant communities on both upland and bottom land sites which meet landowner objectives, and

- Promote resource conditions which allow for an effective water cycle.

Animal numbers should be allowed to fluctuate associated with climate and management, but animal numbers can not be allowed to cause long-term degradation to soils or vegetation. Managers need to be able to determine if grazing is meeting objectives or are within the "limits of acceptable change" by monitoring. Monitoring should consider biophysical indicators of degradation such as soil and vegetation changes ${ }^{8}$ and livestock condition, and should stress key areas or monitoring key resources. If livestock grazing is resulting in significant soil erosion, stream bank damage, or some other resource concern. management should be adjusted which may include a change in livestock numbers, providing other sources of forage, altering timing of use, etc. Key to the management of livestock will be effective planning with the communities of users. In the future the Department of Natural Resources should work with livestock producers and local communities to ensure sustainable grazing and resource management and to reduce conflicts where pastoralists are managing animals on government or communal lands.

\footnotetext{
" Soil changes monitored may include decreased fertility, decreased water holding capacity, decreased infiltration, and accelerated soil loss. Vegetation changes monitored may include changes in productivity over time, unrelated to climate, changes in vegetation cover, changes in plant species composition, shift in vegetation states, etc.
} 


\section{Task E: Literature Cited}

Bakhtani, N. 2004. Traditional knowledge of agro forestry models in Afghanistan. Paper presented at the $4^{\text {th }}$ International Conference on Yak, Chengdu, China. September 20-26. 2004. Session 7. 4 p.

Bartels, G., G.K. Perrier, and B.E. Norton. 199I. The applicability of the carrying capacity concept in Africa: a comment on the thesis of Leeuw and Tothill. p. 25-32. In: R.P Cincotta, C.W. Gay, and G.K. Perrier (eds.), New concepts in international range management: theories and applications. Proc. 1991 Int. Rangel. Symp., 14 Jan., 1991, Washington, D.C. Utah State Univ. Logan, Utah.

Bartels, G.B., Norton, B.E. and Perrier, G.K. 1993. An examination of the carrying capacity concept. In: Range Ecology at Disequilibrium, new models of natural variability and pastoral adaptation in African savannas (Eds. Behnke. R.H.. Scoones, I. and Kerven, C.). pp. 89-103. ODI, London.

Behnke, R.H. and Scoones, I. 1993. Rethinking range ecology: Implications for rangeland management in Africa. In: Range Ecology at Disequilibrium, new models of natural variability and pastoral adaptation in African savannas (Eds. Behnke, R.H., Scoones, I. and Kerven. C.). pp. 1-30. ODI, London.

Casady, G.M. nd. Rangeland assessment of Ghazni and Zabul Provinces, Afghanistan. Report for the International Organization for Migration, Kabul, A fghanistan.

Casimir, M. R.P. Winter, and B. Glatzer. 1980. Nomadism and remote sensing: animal husbandry and the sagebrush community in a nomad winter area in western Afghanistan. J. Arid Environments 3:231-254.

Caughley, G. 1981. What is this thing called carrying capacity, p. . In: M.S. Boyce and L.D. Hayden-Wing (eds), North American Elk: Ecology, behaviour, and management.

Ellis, J.E. M.B. Coughenour, and D.M. Swift. 1991. Climate variability, ecosystem stability, and the implication for range and livestock development, p. 1-12.. In: R.P. Cincotta. C.W. Gay, and G.K. Perrier (eds.), New concepts in international range management: theories and applications. Proc. 1991 Int. Rangel. Symp., 14 Jan. 1991. Washington, D.C. Utah State Univ. Logan, Utah.

Holechek, J.L., R.D. Pieper, and C.H. Herbel. 1996. Range management: Principles and practices. Prentice-Hall, New Jersey, USA.

McArthur, I.D., Sayad, S. and Nawim. M. 1979. Rangeland livestock production in western Afghanistan. J. Arid Environment 2:163-179.

Moris, J. 1991. Organizational models in the development of African pastoralism. p. 3-64. In: 
R.P. Cincotta, C.W. Gay, and G.K. Perrier (eds.), New concepts in international range management: theories and applications. Proc. 1991 Int. Rangel. Symp., 14 Jan. 1991, Washington, D.C. Utah State Univ. Logan, Utah.

Perrier, G.K. 1990. The contextual nature of range management. Pastoral development network, Pater 30c. London, ODI.

Qi, J, R. John, and J. Li. In press. Rangeland information products from remotely sensed imagery for management decisions and environmental assessment in Afghanistan.

Sayer, J.A. and A.P.M. van der Zon. 1981. Afghanistan: National parks and wildlife management. A contribution to a conservation strategy. Volume I. FO: DP/AFG/78/007. Technical Report, Vol. I.

Sheehy, D.P.. J.W. Stuth, W.T. Hamilton, and J.R. Conner. 1991. An approach to implementing sustainable use of grazed ecosystems. World Resource Review 3: 74-94.

Toderich, K. and Tsukatani. 2005. Water/Pasture Assessment of Registan Desert (Kandahar and Helmand Provinces). Discussion Paper No. 606. Kyoto Institute of Economic Research. Kyoto University, Kyoto Japan. http://www.kier.kyoto-u.ac.jp/index.html. November 2005. 


\section{TASK F: An Analysis of Current Rangeland Management Practices and User Rights and an Assessment of the Sustainability of Such Practices Relative to Rangeland Productivity Levels.}

There is no larger constraint to proper resource management than conflicts associated with land tenure and/or land access and control of key resources. In this section I have cited many of the recent works on Afghan land tenure issues, but I have not gone into detail as I am not a land tenure specialist. In regards to rangeland uses and user rights one will likely find significant differences associated with different histories and cultural groups, and the relationship between cultural groups and users. The four types of land ownership listed for Afghanistan are private lands, joint ownership by tribe or clan, community land, and government land (MAAHF, 2005). Grazing rights in Afghanistan are a particularly contentious issue (Weijer, 2005): ADB, 2005 ) and in all types of land ownership there are numerous issues regarding proof of land ownership and property right claims associated with unclear ownership documentation. poor cadastral services, and state registration documentation destroyed during the recent wars and conflicts. Joint ownership by tribe or clan is included in Afghan land code and is regarded as a primeval form of community ownership. Community land is land owned by the community and is recognized by the central government and apparently the central government recognizes its utility and viability (MAAHF, 2005). Government land is all land that is not private, however the terms meaning is unclear. It is not clear if government land refers to national property of which the government is the trustee, state property of which the government is the administrator, or land owned by the Government and exploited by and for its staff (MAAHF, 2005 pg. 6).

To bring order to the use of public lands, and likely community lands, it will be necessary to integrate user rights into a local land use planning process. Alden Wily (2004) has provided an outline for an approach to pasture dispute resolution ( $\mathrm{p} .88$ ). This document provides an indepth synthesis of land tenure problems in Afghanistan. In the following paragraph I very briefly review some historical aspects regarding user rights issues for nomadic pastoralists.

A large majority of nomads are Pashtun. but nomadic pastoralists are also found among the Aimaq, Baluch, Central Asian Arabs. Kirghiz, Turkmen, and Uzbeks (Barfield, 2004). Barfield (2004) states that "nomads generally have exclusive access to specific seasonal pastures

\footnotetext{
"The contentious issue of land rights is illustrated by the statement from Weijer (2005): "In the present days. the traditional system of pasture rights seems in some cases to be replaced by the power of the gun. Local power relations often determine the rights of access."
} 
and move between lower elevation winter pasture to high elevation summer pastures as parts of a regular pattern of migration." He stressed that Afghanistan pastures have always been treated as "private property" of the pastoral groups that used them. However, it is certain that this "exclusivity" has broken down and certainly to some extent has always fluctuated with changing power bases (for example, the Pashtun groups that assisted Amir Abdur Rehman's conquest of the Hazarajat received land grants for use of the Hazarajat lands). Rights to pastures were recognized by government firmans (decrees) made either to specific kinship groups or important families or in some cases pasture rights were validated primarily by continual exclusive use (Barfield 2004). In some areas pasture rights have been inherited over the generations, but in some instances the decrees have been relatively recent such as in northeastern Afghanistan where pasture rights were reorganized following the reorganization of the region's administration in the 1920s (Kushkaki 1979 from Barfield 2004).

Glatzer (1992) describes two types of legal access to pasture: (1) rights to pasture, and (2) permission to use pasture (mediate and intermediate rights) in Afghanistan. Pasture rights were held by individual households; even though several households may form temporary groups for making use of their rights jointly. Barfield (2004) writes that nomads who lacked formal ownership rights to pasture or those that did not have enough pasture could acquire pasture on a temporary basis by formal lease or paying a fee (Barfield 2004). The lease or payments of fees to use pastureland was both a normal and useful practice as it served to prevent overgrazing as owners would allow no more than a specific number of animals on each pasture (Barfield 2004). Balance between herd numbers and pasture was also maintained by sedentarization of both rich and poor herders (Barth 1961 from Barfield 2004). The poor settled as they did not have enough animals and the rich settled when they purchased agriculture lands. Barfield (1981, from Barfield 2004) found that this pattern (for rich herders) began to change in the 1970s when the value of sheep rose so sharply that wealthy pastoralists and even merchants began to hire shepherds to take their animals to summer pasture without their families.

An attempt by the Afghan government to project some authority over pasturelands was the "Afghan Pasture Law"of March 10, 1970 (Barfield 2004). As this law was enacted to "protect" pasture from degradation it is likely that pasture conflicts have long been a common occurrence. However, Glatzer (1992) and Barfield (2004) note that the law had no real impact on rural Afghanistan and reports that few nomads were even aware that such a law existed. 
Alden Wiley (2004) provides a thorough listing of A fohan pasture legislation (p. 94-97). A number of acts cover livestock grazing, conversion of grazing lands to croplands, descriptions of land types, and much more, but it is difficult to determine how relevant these laws are under the current situation.

Thieme (nd; p. 16) suggests conflicts arise between settled livestock owners and nomadic pastoralists because of different main interests. With settled livestock owners their main interest is crop production and do not consider the sustainability of natural grazing lands. Nomadic pastoralists have always been interested in maintaining grazing lands and provide sustainable use by grazing rotation and moving livestock seasonally and when forage supplies are marginal. For settled livestock owners there is more limited movement of livestock and apparently often a conflict with nomadic users that may have been traditional users of the same areas. Thieme (nd) and Favre (2003) found that plowing of sub-marginal land in the hope of a quick return is widespread where the topography allows the use of tractors. Thieme (nd) suggests that in the Northern Plains and in the Herat Region "rainfed" cultivation has recently been pushed tar past the limits of reliable rainfall, usually by speculators rather than traditional farmers which has led to considerable destruction of pasture land with few successes in producing crops. It is also known that there has been a "land grab" in areas by the powerful that will have negative impacts of traditional land users (Favre, 2003). Therefore, the plowing of lands is likely associated with land tenure problems and possibly with a lack of knowledge (land suitability classification) about the productive potential of these lands. There is concern that some individuals are plowing marginal rangelands to secure tenure over the plowed lands.

ADB (2005) suggests that the privatization and cultivation of rangelands threatens nomadic pastoral use of traditional grazing lands. They point to the illegal seizure of public lands resulting in de facto control of large areas by neighboring villages. Despite being banned by present legislation, the process of privatization is accelerating (ADB, 2005). Individual farmers, adjacent villages, large landowners, militia commanders and warlords are usually responsible; while local communities. nomadic groups, and the Government itself, are usually the losers.

In summary, there is no question that current conflicts regarding land tenure and access are impacting rangelands; and, as stated previously nomadic pastoralists and the government are the likely losers. ADB (2005) and Alden Wiley (2003 and 2004) stress that the legitimate 
ownership claims to communal land require registration and an indication of the communal user rights and a "link" to a procedure for approved plans for natural resource management at the local, regional, and national levels. There is also a need to develop resource control mechanisms within the communities, for example, the number of animals allowed to graze land at certain periods of the year. These communal land management regimes should be formulated in collaboration with the local agricultural departments and endorsed by the community councils (shuras). Land management systems and procedures for approving change in these systems should be developed and institutionalized (e.g, grazing rights, communal forestry rights). It is well-known that livestock movement, as practiced by nomadic and semi-nomadic peoples, is an effective way of achieving sustainable use of rangelands when pastoralists have access to key resources and there is some control on animal numbers.

\section{Task F: Literature Cited}

Alden Wiley, L. 2003. Land rights in crisis: Restoring tenure security in Afghanistan. Afghanistan Research and Evaluation Unit. Kabul.

Alden Wiley, L. 2004. Looking for peace on the pastures: Rural land relations in Afghanistan. Afghanistan Research and Evaluation Unit. Kabul.

Asian Development Bank (ADB). 2005. Capacity Building for Policy Reform: Land Policy and its Implementation in Afghanistan. TA 4334-AFG. Discussion Draft July 2005.

Barfield, T. J. 2002. Nomadic pastoralists in Afghanistan: Reconstruction of the pastoral economy. Bank Information Center, Washington D. C. www.bicusa.org/bicusa/issues/ Nomadic_Pastoralists_final.pdf

Favre, Raphy. 2003. Grazing Land Encroachment Joint Helicopter Mission to Dasht-E Laili, 25-27 March 2003. FAO FAAHM/AFGHANISTAN OSRO/AFG/111/USA. 23rd July 2003, $20 \mathrm{p}$.

Glatzer, B., 1992, Pastoral Territoriality in West Afghanistan: An Organization of Flexibility. In: Casimir, M.J., Aparna Rao (eds). Mobility and Territoriality; Social and special boundaries among fishers, pastoralists and peripatetics, New York-Oxford, p 293-306.

MAAHF. 2005, October 8 2005. MAAHF and Agriculture Sector Master Plan: Management of natural resources, land, water, forestry, wildlife and rangeland and environmental protection. Draft 03. October 8, 2005. 22 p. 
Thieme, Olaf nd. Afghanistan, Country Pasture/forage resource profiles. Food and Agriculture Organization, Rome. http:/www fao.org/ag/AGP/AGPC/doc/Counprof/atghan/afghan.htm (October 30, 2005).

Weijer, F. de. 2005. National multi-sectoral assessment on Kuchi. Ministry for Rural Rehabilitation and Development, Afghanistan. 50p. (http://www.mrrd.gov.af/vau/nmak.htm). 


\section{Task G. Identification of key rangeland management issues and possible options for their resolution}

\section{Introduction}

The most important issues facing Afghanistan are providing sustainable livelihoods and security to its people. Rangelands are not only critical in providing people with livelihood opportunities in the livestock sector, but act as watersheds, supply humans with fuel woods. provide biodiversity, and provide other resources and intrinsic values. The key rangeland management issue is no doubt related to land tenure/land access issues discussed in the previous section. At the Conference on Pastoralists (kuchi) held in Kabul (November 15-17, 2005) the land tenure/land access issue was so prominent it seemed that few other issues (i.e, overgrazing, winter feed, low animal quality, loss of fuel woods, etc.) were important to the Kuchi members. It is apparent that there are a number of initiatives to address the land tenure problem and that land tenure issues must be solved to allow for proper management of rangelands. As there are currently a number of initiatives regarding land tenure I will only briefly discuss this problem. I will then discuss other problems regarding rangeland conditions.

\section{Land Tenure Issues}

For nomadic or semi-nomadic pastoralists there is a strong need to restore and ensure access to key resources or multiple ecological zones. This must include different seasonal pastures, different vegetation communities (associated with different topographic and macro and micro climate influences), water, shelter for livestock (from wind, cold or heat which may include man-made shelter or "natural" shelter) and grazing flexibility associated with changing environmental situations. Resource access rights not only include the pastures, but migratory corridors and water points that allow for herd movement. The problem of grazing access associated with the years of conflict and other changes is shown in the following excerpt from Favre (2003) for a group of nomads using the Dasht-e-Laily area.

In addition to these groups, that use the Dasht-e-Laily for grazing in spring and summer, there is another group of more long range nomads, that pass through Dasht-e-Laily in early spring and autumn, on their way to or from their summer grazing areas higher in the mountains. Traditionally these nomads, which are predominantly Pashtun. move into the Central Highlands 
where they pass the summer months, either with the entire family or with part of the family. However, in the years of war and conflict, these migration routes have been disrupted to a large extent. and the nomads have been looted, often more than once. Passing through and into area controlled by different commanders and governors proved difficult and dangerous and has caused a change in migration patterns.

In considering nomadic and semi-nomadic pastoralists there is a strong need to consider the community of users and the interaction of these users with other groups. In this sense. strict ownership of land is not the most significant factor for pastoral livestock production: rather, it is access to habitat diversity (spring, summer, fall and winter pastures) and to water and shelter for optimum livestock production. As much of A fghanistan is dominated by non-equilibrium rangelands (and thus a high likelihood of drought and other weather related problems) pastoralists need availability to a wide range of vegetation types or areas. As such, allowing groups to use areas under communal arrangements (common property) with control on access times and numbers of animals will be a desirable arrangement for rangeland sustainability. In the future, there will also need to be more sound land use planning and integrated natural resource management planning; no matter what type of land tenure/land access arrangements are formulated.

\section{Cultivation of Rangelands}

Related to land tenure problems is the issue of plowing traditional pastureland for rainfed crop production. For instance, ADB (2005b, p. 14) states that the lower plateau pasture lands in Bamyan Province are being eroded by rainfed cropping systems. This type of cropping is unsustainable because of unsuitable topography (high erosion hazard), and the high risks of crop failure from drought and cold weather. It was inferred that the families cultivating these areas were doing so because of they had no other alternatives for their livelihood and they would graze the pastures if they had sufficient animals. Favre (2003) examined the situation of plowing rangeland in Dasht-E-Laili in March 2003 and reported significant concerns. He suggested that although Dasht-e Laili is a small part of the grazing land in Afghanistan, its fate is representative of an overall national problem. They noted a high incidence of soil erosion on the more hilly 
areas in southern-western part of Dasth-e-Laili (85\% of rain fed/Lalmi farming is practiced on sloping land - FAO Land Cover Atlas, 1993).

From the report by Favre (2003), and other comments heard in Kabul, it is obvious that plowing of rangelands is a significant problem. Some of the increased plowing is associated with "land grabbing" and thus is a land tenure problem. Other lands are being plowed that have high erosion potential. This is generally considered a land use problem associated with a lack of knowledge of the ramifications of plowing marginal lands. A land use suitability classification system needs to be developed to provide people and policy makers with information on the inherent problems of plowing steep, shallow, or unproductive lands. The suitability classification should describe the potential impact of plowing these lands on adjacent areas. watersheds and/or long term productivity: and provide information on the best use of these types of lands (grazing or possibly wildlife). A land suitability classification should rate the degree of sensitivity of lands to plowing and describe conservation practices that reduce problems firom plowing. In cases where land suitability classification states that the erosion risks are great. people should be held responsible for any damage (for example filled irrigation ditches associated with soil erosion from plowed areas) caused by improper land use.

\section{Rangeland Degradation/Condition}

Rangeland condition is a significant concern for policy makers because of the multiple products and values supplied by rangelands. These products/values include forage and browse for livestock and wildlife, biodiversity, clean water, fuel, carbon sequestration, and aesthetic values. Currently, there is no information on rangeland conditions or information on procedures to improve degraded rangelands. Also, the institutional capacity for managing Afghan rangelands for sustainable use is highly suspect because of a loss of educated and trained people during the war years. Sayer and van der Zon (1981) comment on the overgrazed conditions of rangelands, the impact of land uses on biodiversity, especially wildlife species such as ungulates and predators, and tourism over 30 years ago. Asian Development Bank (2005, p. 14) discusses problems in the lower plateau pastures that were suffering major erosion damage in areas closest to the larger settlements. This was associated with local overgrazing and collection of shrubs for fuel. Afghanistan is considered highly susceptible to desertification. Where widespread grazing 
has reduced vegetation cover and exposed soils to erosion many communities have had to significantly reduce livestock numbers because of the reduced quality of rangelands (MAAHF, 2005).

Some may question our ability to define overgrazing in much of Afghanistan, but rangeland managers realize there are both negative and positive impacts associated with livestock grazing that can be determined with monitoring. When animal numbers are too high, or animals are not rotated to allow some "rest" from grazing, or animals graze during the wrong season there will be negative impacts on watersheds and other rangeland values resulting in conflicts with stakeholders. There needs to be monitoring by pastoralist and natural resource professionals to determine impacts of grazing animals on resource values. A significant related concern is the impact of human use on fuel woods (including trees and shrubs). It is well-known that woodland and forest cover has been significantly impacted by human uses, especially during the last several decades, but the question of the impact of uprooting shrubs on soils and the productivity of rangelands is largely unknown. Uprooting of shrubs, notably Artemisia, for fuel is a very serious and widespread problem (Thieme, nd). Thieme (nd) and others (views expressed in Kabul) believe this is not just a question of a villager having to find fuel to cook their food, but traders who organize the uprooting and purchase the shrubs from remote areas to supply urban markets. Sayer and van der Zon (1981) provide a thorough review of biodiversity values, but there is no doubt the situation has greatly deteriorated since their study. Others have reported that riverbanks are eroding with the loss of stabilizing vegetation, and flood risks are increasing. Restoration of vegetation cover is a high priority to combat erosion, desertification and flood risks.

\section{Droughts}

The frequency and severity of drought is a concern to pastoralists and government officials. During the recent drought (1998-2002) livestock losses were severe. Thomson and others (2003) reported losses of $70 \%, 77 \%, 72 \%, 82 \%$ and $86 \%$ for cattle, sheep, goats, horses and camels, respectively for 183 villages in 5 provinces using mixed crop/livestock systems. Losses for nomadic pastoralists in the Registan Desert were also reported to be very high ( $90 \%$ of sheep and $40 \%$ of camels) and many households lost all of their livestock (Degen and Weisbrod, 2004; Central Asian Development Group, 2004). Glatzer (1981) reported losses of 
$90 \%$ of animals in the spring of 1972 in west A fghanistan associated with drought, but also related to the increased cost of grains. As grain costs increased (because of shortage of grain) and livestock prices decreased (as there was little feed) it required selling more animals to buy the same amount of grain. The large fluctuations in livestock numbers is a concern because of the impact on livelihoods and the ability to recover from these shocks. Glatzer (1981) reported that many nomads relied on farming after losing most of their herds, but their goal was to become nomadic when they could increase their animal numbers. They considered farming as very risky in the dry and variable environment of western Afghanistan.

Mobility was traditionally the key pastoral risk avoidance strategy in nomadic societies. Mobility decreases as a result of various socio-political reasons, often associated with increased human population, as pastoralists lose access to key resources. As mobility is decreased and/or there are losses of key resources for pastoralists, options for reducing the impacts of droughts become more limited and costly. Livestock feeding programs and increasing water points for mitigating drought impacts have been costly and controversial as the programs have often exacerbated over grazing problems. Morton and others (nd) working in Kenya found that the most important drought mitigation intervention was emergency livestock purchase by outside groups. They reported that destocking achieved several desirable results. It allowed pastoral households to liquidate some their capital assets (livestock) before they were lost: thereby, increasing the purchasing power of these households. The "destocking" by outside purchase kept the value of animals high. Destocking also created a market for weaker animals, thereby enabling herders to keep stronger animals for post-drought recovery; reduced overstocking around villages, and improved nutritional status of poor households as meat was often redistributed to the poor and to schools.

In the southwest U.S. (largely non-equilibrium rangelands), conservative stocking rates have resulted in better long-term returns to ranchers associated with improved forage availability, better animal condition. less feeding. and less need for selling animals when animal values are low because of drought (Holechek. 1991). Increased animal numbers (high stocking rates) often maximize gross economic returns, but net returns are maximized by moderate or conservative stocking levels (Holechek and others, 1996. pg. 198). The applicability of prescribing conservative stocking rates to Afghan pastoralists seems difficult at best: however, increasing herd/animal numbers (often considered as a recipe to mitigate production risks) may 
have more negative environmental impacts through overgrazing or trampling so that short-term reduced production risk may lead to long-term decreased natural resource base. Baas and others (2001) suggest that increasing animals numbers increases the production risk in the long run and add to environmental risk by reducing the natural environments resilience to harsh climatic conditions. They stress that risk management strategies need to consider the environmental resource base, environmental monitoring and sustainable resource use practices as an inherent and integral core part of any strategic planning and suggest four stages of action to mitigate environmental risks for pastoralists:

Stage 1. Preparation for risk reduction and risk avoidance (long-term, ongoing). Preparation for risk reduction and avoidance refers to long-term activities and structures, which prepare the herding economy and the authorities on an ongoing basis for stress periods such as winter, and for unexpected shocks.

Stage 2. Risk planning (annually). Risk planning includes activities that prepare the herding economy on an annual or biannual basis for stress periods such as winter, and for unexpected shocks.

Stage 3. Reacting to risk (when disaster occurs). The need to react to risk occurs once a risk turns into an acute threat and detriment occurs. This phase requires immediate action. It is more likely that successful action can be taken, if good planning and preparatory steps were taken.

Stage 4. Recovering from risk (when detriment has occurred). Recovery fiom risk is a key process, since until the household economy has recovered it remains especially vulnerable to new risks. The scale of detriment/loss and of support needed at this stage is determined on the one hand by the gravity of a calamity and on the other hand on the quality, quantity, and co-ordination of actions taken in the previous stages.

The ability of national and provincial governments to guide people through the next drought is suspect. Bhattacharyya and others (2004) reported that Afghan government antidrought policies and practices were at the embryonic stage. They also reported that village-level institutions like shuras and water wackils were not meeting the expectations of the farmers to manage scarce water efficiently or equitably. An emerging commission at the central level and its regional suboffices may give some focus to drought-related issues; however, it will take a long time before its benefits are felt at the ground level mainly because of poor extension systems (Bhattacharyya and others, 2004). Program initiatives proposed by MAAH and MIWRF 
(2004) also address water and drought issues and some aspects of drought planning. CRS (Catholic Relief Services) have also proposed micro-ivatershed development assistance in Afghanistan.

To reduce the impact of drought on pastoral households Afghanistan must develop an early warning system (EWS) for drought and a mitigation plan. This EWS and mitigation plan should be a program to prepare for drought, for risk planning, for reacting to drought. and recovering from drought. These efforts should be guided by government at the national level. but those at the provincial level and district level will need to work effectively with local communities as the local people must be the driving force for much of the plan implantation. This will require extension activities and incentives and disincentives. For pastoral ists, the use of natural resources should be planned in coordination with the Department of Natural Resources, but with extension help and coordination with other departments with MAAHF. Baas and others (2001) provide a detailed summary of actions to prepare herding communities for risk planning and for reduction of the impacts associated with environmental risk. Key is the planning process and working with policy makers to provide mechanisms for reducing environmental risk and the impacts of drought. For example, incentives to reduce overgrazing, improve range conditions, and provide market opportunities. Stuth and others (http://cnrit.tamu.edu/lews/) have developed a livestock early warning system (LEWS) that has shown promise in helping pastoral communities in developing countries deal with droughts. Developing a similar program in Afghanistan would help provide timely information on forage conditions and animal nutrition and help forecast drought effects and interventions to decrease the impacts of drought on pastoral communities ${ }^{10}$.

Therefore, there is a strong need to increase the institutional capacity for classifying rangeland types, for determining the proper use of rangelands (including integrated resource management planning to ensure community based plans on government or public lands), and to monitor rangelands to ensure sustainable use or improvement of degraded lands. Drought planning is a necessary part of developing integrated resource management plans. Until

\footnotetext{
${ }^{10}$ LEWS uses a satellite-based weather and vegetation greenness technology coupled with biophysical models to predict forage condition and, along with animal nutrition monitoring technologies and information teclonology for markets, allows pastoralist and decision-makers to be proactive in implementing appropriated rangeland livestock management practices or intervention to protect the natural resource base and decrease impacts on livelihoods of pastoralist using the rangelands.
} 
institutional capacity is sound the international community should consider programs that improve off-take of livestock during droughts to decrease the impacts on rural livelihoods.

\section{Task G: Literature Cited}

Asian Development Bank. 2005, February. Capacity building for reconstruction and development. Component 1B.2: Agruculture and Natural Resource Management Planning. Annex 2 (volume 2). TA No. 3874-AFG. Forest and Rangeland Management.

Baas, S. Liu Yongong, and J. Swift. 2001. Guidelines for developing improved risk assessment, prevention and management approaches in pastoral areas of Northwestern China. Sustainable Development Department, Food and Agriculture Organization. http:/www. fao.org/sd/2001/1N0602a en.htm (November 2005).

Bhattacharyya, K.; Azizi, P. M.; Shobair, S. S.: Mohsini, M. Y. 2004. Drought impacts and potential for their mitigation in southern and western Afghanistan. Working Paper 91. Colombo, Sri Lanka: International Water Management Institute. WORKING PAPER 9. Drought Series. Paper 5. ISBN 92-9090-589-1

Central Asian Development Group. 2004. Registan Water/Pasture Assessment (UNAMA). Final report July 20, 2004. 129 p.

Degen, A.A. and N. Weisbrod. 2004. Can pastoral nomads return to their traditional livelihood of raising livestock in the Registan desert of southern A fghanistan. Nomadic Peoples 8 (2):214-229.

Favre, Raphy. 2003. Grazing Land Encroachment Joint Helicopter Mission to Dasht-E Laili, 25-27 March 2003. FAO FAAHM/AFGHANISTAN OSRO/AFG/111/USA. 23rd July 2003, 20p. http://www.fao.org/world/afghanistan/pubs_en.htm

Glatzer, Bent. 1981. Process of nomadism in west Afghanistan, p. 61-86. In: Salzman. Philip, Carl (ed). Contemporary Nomadic and Pastoral Peoples: Asia and the North. Studies in Third World Societies (Department of Anthropology). College of William and Mary. Williamsburg, Vir., Publ. No. 18.

Holechek, J.L. 1991. Chihuahuan desert rangeland, livestock grazing and sustainability. Rangelands 13:115-120.

Holechek, J.L., R.D. Pieper, and C.H. Herbel. 1996. Range management: Principles and practices. Prentice-Hall, New Jersey, USA.

Khan, Ulfat-un-Nabi and Muzaffar lqbal. Nd. Role and the size of livestock sector in Afghanistan. A Study Commissioned by The World Bank, Islamabad, Draft Report. http://nweb 1 8.worldbank.org/SAR/sa.nsf/Attachments/95/\$File/afl vstk.pdf (November 2005). 
MAAH (Ministry of Agriculture and Animal Husbandry and MIWRE (Ministry of Irrigation, Water Resources and Environment) and Science Academy 2004. Natural Resource Management Public Investment Program. Submission to the Ministry of Finance for the SY 1383-1385. March 2004

MAAHF. 2005, October 8 2005. MAAHF and Agriculture Sector Master Plan: Management of natural resources, land, water, forestry, wildlife and rangeland and environmental protection. Draft 03, October 8, 2005. 22 p.

Morton, J., D. Barton, C. Collinson and B. Heath. Nd. Comparing drought mitigation interventions in the pastoral sector. htp //www.nri.org/projects/pastoralism/interventions.pdt (Nov. 2005).

Sayer, J.A. and A.P.M. van der Zon. 1981. Afghanistan: National parks and wildlife management. A contribution to a conservation strategy. Volume I. FO: DP/AFG/78/007. Technical Report, Vol. I.

Thieme, Olaf (with contribution by J.M. Suttie) nd. Afghanistan, Country Pasture/forage resource profiles. Food and Agriculture Organization, Rome. http://www.fao.org/ag/AGP/AGPC/doc/Counprof/afghan/afghan.htm (October 30, 2005).

Thomson, E., T. Barker, J. Mueller. 2003. Drought, livestock losses and the potential for feed production from arable land in A fghanistan: A case study of 183 villages with mixed crop/livestock farming systems. Integrated Natural Resource Management Research Report Series, No. 5. ICARDA, Aleppo, Syria, 34 p. 


\section{Task H. Rangeland policy and strategies for sustainable management.}

\section{Introduction}

Rangelands, defined as uncultivated lands that supply a grazing or browsing resource to domestic and wild animals, are by far the major land type in Afghanistan comprising between 70 and $80 \%$ of the country. The sheer size and diversity of resources supplied by Afghan rangelands require that they receive greater emphasis in future development and research with the Afghan government, international development organizations, and the world environmental community. Rangelands provide a significant amount of the current feed source to the livestock of Afghanistan; yet, there is little information regarding the role natural pastures play in the livestock industry. Livestock have been critical to the economy of Afghanistan by providing high quality products for domestic use and export. In the 1970s, agriculture supplied approximately $50 \%$ of the Gross Domestic Product (GDP) and livestock supplied about $25 \%$ of the agriculture GDP. In addition, livestock supply a source of protein and a dense source of nutrients to humans. The integration of extensive and intensive pastures is important where they occur together and must be considered together in planning for livestock projects. Nomadic pastoralists with their traditional lifestyles offer a unique cultural identity, and are often the major users of extensive pastures. It is my contention that livestock products as well as other rangeland products (wildlife, water, etc.) could be significantly improved with better rangeland and livestock management. In addition, improved management that ensures sustainable use of rangelands would also be more likely to conserve or support traditional lifestyles and cultures.

Afghanistan has an opportunity to develop a natural resource policy that will provide for sound use of natural resources and improved economic efficiency from products associated with its natural resources. The critical question is how can any rangeland policy balance local and national needs with sustainable pastoral production given today's socio-economic realities in Afghanistan? Key to providing the opportunity for sustainable resource management is the need to initiate land use controls and land tenure systems that are appropriate for Afghanistan. In addition, special attention should be given to finding proper balance between the roles of government entities, the private sector, and pastoral communities. Traditional pastoral systems that provided sustainable grazing in Afghanistan require special evaluation for adoption where feasible under current conditions. There is no doubt that collaborative management of natural 
resources is necessary to achieve sustainable use and to lower costs to government ${ }^{1 !}$. Richard and Miller (1998) list the following points that collaborative rangeland management policy should seek to provide:

- Make tenure and property rights clearly understood among all stakeholders;

- Provide a supportive legal framework and political environment that legitimizes local communal institutions such as formal grazing associations or informal grazing user groups;

- Identify the constraints and promote the unique opportunities that each area offers through effective participatory research and development;

- Increase income from livestock production via improved market links between producers and consumers, through formation of marketing cooperatives and/or trade associations;

- Improve living standards among pastoral groups by providing better access to education, veterinary facilities, medical facilities, and improved living conditions (meaning services must be mobile or seasonally located);

- Provide education that is appropriate to the particular region by enhancing vocational skills that are pertinent to the livestock profession and that give producers a comparative advantage in market negotiations (language, accounting. processing, marketing, para-veterinary skills, etc.).

In the following sections I discuss policy and strategies necessary to achieve sound rangeland management. A previous report by ADB (2004) discussed relevant and needed forestry and rangeland policy. I will not repeat their recommendations, but will suggest policy and specific strategies to better achieve sustainable rangeland uses based on my review of problems and issues during my consultancy. Weijer (2005) also provides support strategies for Afghan pastoralists (outline shown as Appendix 14) which I believe contains many of the same needs that I have stressed in the following sections. In have stressed rangeland issues and institutional development within the Department of Natural Resources. but this does not infer that related aspects regarding animal production and husbandry, macro-economic regeneration, and potential mechanisms to support the establishment of substitute livelihoods is not critical, as they are. I consider these aspects directly interrelated to rangeland issues and consider them a

\footnotetext{
"Collaborative management involves a situation where government authorities and local communities reach an agreement and establish rights and responsibilities regarding resource management (Fisher 1995).
} 
part of the strategies/programs presented ${ }^{12}$. I stress that the Afghan people must show a strong commitment to solve natural resource problems. However, I believe the international community must assist Afghans to develop the institutional capacity to solve many of their natural resource problems because of the recent conflicts, severe drought, and because it is one of the world's poorest countries. As Afghanistan is blessed with large areas of natural pastures or rangelands it is critical that the management of these lands receive priority to achieve growth in the pastoral economy and improved ability to manage these areas. This will require institutional development, including improved education and knowledge of these systems, and a concerted effort to look at these systems holistically with other resources and enterprises.

\section{Policy Overview}

A rangeland policy must realize the value of rangelands to the national economy for producing not only livestock products, but as watersheds, wildlife habitat (biodiversity), carbon sequestration, and open space and aesthetic values for human spiritual well-being. A rangeland policy must conserve (provide for sustainable uses) rangelands for future generations, but must also develop policies that balance local community(s) needs with its policy. In some instances rangeland use may stress sustainable animal production; whereas, in other areas rangeland use may stress wildlife values, watershed values, carbon sequestration or other values. In management of State owned rangelands collaborative management will be stressed to ensure reduced management costs to the government and better management of the resource. National rangeland policy must direct a national plan to categorize and understand rangeland ecosystems. This will include a classification of values (productivity, variability, products including forage. biodiversity, etc), determination of the state of rangeland health (including desertification. degradation, watershed condition. etc.), and land suitability for different uses (cultivation. grazing, etc). Where rangelands are not producing at their potential there will be an assessment of the causes of degradation and potential rehabilitation methods. All Ministries involved in natural resource management (for example MAAHF and MIRWE) and those involved with rural peoples and nomadic peoples (for example MRRD and MFTA) will be stakeholders in rangeland

\footnotetext{
12 For example, livestock improvement (quality of animals and products) and marketing are considered in the development of collaborative plans. Alternative livelihoods (and education) are considered under the drought planning and management program. Thus, extension activities, research, and education (crossing several departments and ministries) to help pastoralists optimize animal production and economic efficiency are critical aspects for improving livelihoods and to achieving sound resource management.
} 
policy and strategies and will interact in setting policies and strategies. However, it is apparent that the Department of Natural Resources (formerly Department of Forestry and Rangelands) should be the lead agency in directing rangeland policies and strategies.

\section{Strategy and Needs for Achieving Rangeland Sustainability}

The suggested strategies for sound rangeland management listed below are based on the issues and needs determined during this consultancy. I have subdivided these strategies into five programs: (1) Rangeland Inventory and Classification; (2) Drought Preparedness and EWS; (3) Integrated Natural Resource Management Planning; (4) Rangeland Monitoring ${ }^{13}$; and (5) Capacity Development (education and training). All of the strategies are interrelated and will be ongoing programs directed by the Department of Natural Resources and are only briefly described below. I suggest these strategies be expanded with future coordination and discussion with the Department of Natural Resources. Each of the programs will also require institutional capacity development through training and education, a strategy in itself, and likely the most important strategy. It is recognized that the administrative structure of the government of Afghanistan is further divided into provincial, district and village levels and it will be at the local or community level where management actions will best ensure productive use of rangelands. Government agencies must work with local user groups to understand the limitations and opportunities of different systems to most efficiently and properly manage natural resources. In order to demonstrate or "tie" these five strategies together I propose the development of a number of pilot projects that would initiate these different programs. I have not suggested locations, or selection criteria for different pilot project areas, but only suggest that pilot projects would be valuable for training and in providing additional information to allow for future planning endeavors.

\footnotetext{
${ }^{13}$ I have listed rangeland monitoring as a separate strategy, but it is also a major activity of the integrated natural resource management planning strategy. I separated these strategies as there will be plan monitoring and national monitoring of rangeland conditions.
} 


\section{Rangeland Inventory and Classification (including Land Suitability)}

A national program to inventory and classify rangelands should be developed with the immediate goal of increasing basic knowledge about these systems. Initially, this would be a broad based classification utilizing existing information with additional site information developed with remote sensing applications. Rangelands would be classified and related to physical parameters (climate/drought hazard, history of land use, topography, slope and soils) and placed into a geographic information system (GIS). Remote sensing should be used to classify the variability of rangelands and provide landscape based information for policy advisors. In the future, rangelands will be classified into ecological sites or ecological response units to improve information on resource values (including plant community information. biodiversity aspects, etc.), seasonal plant production, variability in production and methods of improving degraded conditions.

As plowing of marginal lands was identified as a major concern, a land suitability classification should be an initial and significant part of this program. Land suitability is the fitness of a given type of land for a defined use and is generally based on soils, topography, climate, and management. In general, a land suitability classification recognizes categories applied to different kinds of land use with decreasing generalization. For example, Land Suitability Orders reflecting kinds of suitability: Land Suitability Classes reflecting degrees of suitability within Orders; Land Suitahility Subclasses reflecting kinds of limitation, or main kinds of improvement measures required, within Classes; and, Land Suitability Unit, reflecting minor differences in required management within Subclasses.

As stated previously, the goal of the rangeland inventory and classification system will be to categorize similar rangeland types into ecological response units (ecological sites). An ecological response unit is a site-based system that allows an ecological basis for land use and research and management. A specific ecological response unit is a specific kind of land with physical characteristics that differs from other kinds of land in the ability to produce distinctive kinds and amounts of vegetation and it its response to management. All areas in the same ecological site will have similar potential resource values (biodiversity, carbon sequestration. watershed aspects, etc) and will respond similarly to management when in the same vegetation state. Ecological sites or units will have a number of states, transitions and thresholds that 
should be determined as information becomes available ${ }^{14}$. Ecological units will be used to. evaluate degradation and watershed conditions and potential methods of rehabilitation. The information gained in this program will supply policy makers with information on the health of these systems, major problems and concerns, and opportunities. The information will also be used in development of plans (as will information from developing plans be used in the inventory and classification of rangelands).

\section{Drought Preparedness and Early Warning System}

Droughts are having dramatic impacts on the livelihoods of A fghans. The national government must develop a strategy to help people by developing plans to reduce and mitigate the impacts of drought. In this section I propose a drought management program that will be concentrated in provinces and districts where droughts are more frequent and severe. The program strategy will consist of early drought warning. long term ongoing risk reduction and risk avoidance strategies, risk planning, drought intervention activities (reaction phase), and plans to recover from risk (also see summary of steps in task $G$ ).

Critical to developing an ability to respond quickly to droughts is an early warning system. The Livestock Early Warning System (LEWS) developed by Stuth and others (http:/cnrit.tamu.edu/lews/: December 8,2005 ) is a system that has achieved success in Africa and it is actually much more than an early warning system. LEWS uses a satellite-based weather and vegetation greenness technology coupled with biophysical models to predict forage condition and, along with animal nutrition monitoring technologies and information technology for markets, allows pastoralist and decision-makers to be proactive in implementing appropriated rangeland livestock management practices or intervention to protect the natural resource base and decrease impacts on livelihoods of pastoralist using the rangelands.

In addition to an early warning system such as LEWS, the drought strategy would develop mitigation plans/programs lor preparing for drought, for risk planning, for reacting to drought, and recovering from drought. These efforts should be guided by government at the

\footnotetext{
14 A state is a recognizable, resistant and resilient complex of the vegetation structure and soil base. Transitions are trajectories of change caused by natural events or management actions which alter primary ecological process. Thresholds are boundaries between states.
} 
national level. but those at the provincial level and district level will need to work effectively with local communities as the local people must be the driving force for much of the plan implantation. This will require extension activities and incentives and disincentives. For pastoralists, the planning of use of natural resources should involve direction from the Department of Natural Resources, but with extension help and coordination with other departments with MAAHF. Drought planning will be coordinated with developing integrated resource management planning (next section) and may include a number of programs (financial programs to recover from drought, livestock insurance, herder collectives for marketing opportunities to reduce animal numbers, storage of feed reserves or reserve pastures, etc.) that would be part of management plans developed with pastoralists.

\section{Integrated Resource Management Planning}

Advancing sustainable grazing practices will require development of sound resource management plans that consider other natural resource issues (watershed values, biodiversity, fuel wood, etc.) as well as people and their livestock. I suggest that the development of sound resource management plans will require institutional development, as well as field and classroom training, to initiate effective planning. The establishment of a management planning system requires a number of activities. For example, (1) it is necessary to establish an infrastructure for management planning that brings together people and institutions involved; (2) it is necessary to acquire, process, and analyze information: (3) it is necessary to define and implement alternatives, and; (4) it is necessary to monitor and assess planning activities and to adapt management where necessary. An outline of a basic resource management plan is shown as Table 8 . This outline is not all-inclusive, but does provide a model for resource management planning. The planning outline considers people and their livelihoods, the development of a forage balance and grazing management plan, and project development following selection of objectives and selection of alternatives (including potential interventions such as marketing projects, development of cooperatives, rangeland improvements, development of fodder resources, etc.). To have a successful sustainable resource management plan requires the plan to be a coordinated resource management plan. In other words, the plan is formulated by the people involved, and considers a broad range of resource values (wildlife, recreation, livestock. 
etc.) (in-line with MAAHF 2005); however, the consideration of multiple values does not mean that one use, such as livestock, will be considered the primary use.

Where there are several users and/or landowners, the development of a sound integrated resource plan is very complex, but critical for sound land management. Where government or public land is used for grazing, the Department of Natural Resources will facilitate land use planning with pastoralists using collaborative management. Where only private rangeland is involved private land owners may request help in planning. I have described an integrated planning process in greater detail as Appendix 15. Where there are a number of resource values to consider, especially related to public lands, a systems analysis procedure is recommended. This procedure is briefly reviewed as Appendix 16. Natural resource community based plans developed with stakeholder communities using an integrated planning procedure and a system analysis approach will ensure that economic considerations as well as the plant communities. watershed values, biodiversity, and other values are considered within the social and cultural setting. The strategy is to provide information and guidance, and to integrate the knowledge of pastoralists and other users, to develop a shared vision of the desired future conditions of planning areas and to improve Afghan rangelands. The Department of Natural Resources should work with communities to: (1) make land tenure and land access rights clearly understood by stakeholders: (2) establish a system of sustainable land use by providing the legal framework for grazing institutions or users under the existing land tenure/access regime; (3) develop land suitability assessment procedures including development of values associated with types of rangelands and forage use; (4) evaluate with stakeholders constraints and opportunities needed for restoration/rehabilitation activities. improvements in facilities or production systems, market links, or other skills to improve livestock production/marketing skills; and. (5) provide users with resource management information (extension and research) ${ }^{15}$. Where drought or other risks are prevalent the plan will consider these risks and develop mitigation plans (see previous section on drought preparedness and EWS). In many cases planning will require integration of extensive pastures with intensive land uses to achieve maximum sustainable livestock production.

\footnotetext{
15 Research, extension, and education are interrelated with all strategies. I stress that extension, research, and education will be critical in showing the importance of proper management of livestock to achieve efficient animal production. More emphasis should be placed on animal health and quality, including "getting animals through droughts/winters", and on quality of products. With improved management of rangelands and livestock there is a potential for significant improvement in livestock production and natural resource conditions, but the complexity of livestock production should not be downplayed, and research, extension, and education are critical aspects in achieving improvements.
} 
Computer based decision support systems (DSS) could be used in the future to help natural resource managers in analyzing information.

Table 8. Resource management plan outline.

l. Develop an updated $d$ inventory of resources.

A. Setting

1. Ecological (geology, soils, climate).

2. Social/economic

B. Develop ecological response units*.

C. Develop criteria for determining/measuring degradation of ecological response units.

D. Identify biodiversity and other non-consumptive values of ecological response units.

E. Inventory resources.

F. Determine current estimated carrying capacity by ecological response unit and for the total area.

G. Determine current stocking rate by ecological response unit and total area.

H. Determine areas of degradation and degree of degradation.

11. Develop standards for vegetation use of Ecological Response Units.

A. Best management practices (technical studies and extension).

B. Desired future condition (technical studies).

C. Monitoring procedures.

1. Photo-points.

2. Step-points.

3. Nested-frequency plots.

4. Exclosures

III. Initiate integrated resource management planning (using $\mathrm{PRA}^{*}$ ).

A. Determine planning areas (subset of villages) or rationale for area stratification.

B. Define objectives/goals for resource management areas.

C. Establish herder cooperatives or grazing associations to implement plans where applicable.

D. Examine alternatives for resource use and treatments.

E. Determine priority areas of conservation and rehabilitation.

F. Scheduling of projects.

G. Agreements between range users and Department of Natural Resources.

H. Determine monitoring sites.

IV. Implement plans.

A. Range improvements, water spreading, or other treatments where applicable.

B. Rest areas for recovery/seed production.

C. Reseed areas with indigenous species.

D. Rotate grazing to reduce season length of grazing period and allow plants to increase productivity.

E. Monitor and adaptive management.

* An Ecological Response Unit is a type of rangeland with similar values and in its response to management. PRA - Participatory rural appraisal methodology.

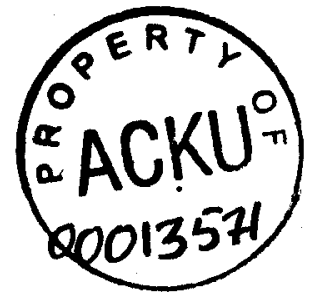


Of critical importance in developing community based plans is the identification of community(s) in which the plan will be developed for and to plan within the social context of the community. This is especially critical in Afghanistan because of the land tenure/access and security issues. At certain locations integrated resource plans may be relatively simple; whereas, at other locations because of diverse groups (such as nomadic pastoralists, farmer-stock growers, farmers, and different ethnic groups) and diverse and/or large landscapes, the planning process may be very complex. Favre (2005) discusses the role of local "shura" used by NGOs and "community development councils" proposed under the National Solidarity Program (NSP). He suggests these groups differ significantly from the traditional gathering of "jirga" or "maraka" called under the authority of influential individuals when tribal/clan conflicts are negotiated or important public issues are to be solved. but also suggests some success in their use. Favre (2005) suggests that the "manteqa" is the actual social and territorial unit of rural A fghanistan. A "manteqa" is composed of several villages or cluster settlements/hamlets where solidarity is shaped amongst the local population. He states that the "manteqa" does not have administrative recognition, although traditional structures/committees exist at the "manteqa" level (i.e. "shura-c" manteqa". "rish safedan-e manteqa", "nomayendagan-e manteqa" or "shura-e mahali". It is obvious that integrated natural resource plans. especially when related to other land use plans, should work closely with community leaders or other socially accepted groups/individuals identified before any planning begins.

All planning should be viewed as an ongoing process and certainly not an end in itself. Goals and objectives will continually be reevaluated as well as needs to develop sound management. Developing an evaluation of goals and objectives with pastoralists and local communities, including the development of monitoring procedures, will be an important part of the planning exercise. Monitoring of rangeland vegetation is discussed as a separate strategy in the next section. 


\section{Rangeland Monitoring}

Rangeland/pasture monitoring is necessary for proper management, sustainable use, and determining how site ecological processes are functioning. Initiating a monitoring program by pastoralists and improving monitoring by the Department of Natural Resources are critical activities. Monitoring studies should be designed and conducted at the level consistent with the needs and objectives. Monitoring by pastoralists will have different objectives than the monitoring by the professional resource managers. In this section, the monitoring strategy is directed towards resource planning areas. I have separated monitoring under subheadings of pastoralists monitoring and monitoring by the Department of Natural Resources. A third level of monitoring not described would be national level monitoring. National rangeland monitoring would provide policy makers with the current state of rangeland conditions. In the future, the Department of Natural Resources should develop a strategy to allow for a quantitative evaluation of changes in rangeland conditions. Much of this information could be developed as part of the strategy in the department's efforts to monitor rangeland conditions in resource management planning areas.

\section{Monitoring by Pastoralists}

Monitoring by pastoralists should be rapid and provide general information on changes in plant communities and current conditions. One of the easier methods of measuring change is to measure vegetation cover. Vegetation protects the soil from raindrop impact, insulates the soil surface from temperature extremes. traps soil particles and protects the soil from wind and water erosion, provides habitat for organisms, and supplies nutrients back to the soil. These factors are easy to explain and demonstrate to pastoralists. In general, photo plots showing different percentages of vegetation cover can be used rapidly and with little training. Utilization guides are also relatively easy to develop and use. These guides should be developed with the agriculture university faculty or researchers in MAAHF for particular sites. Changes in plant communities can be determined from photo-points and notes on plant communities. For pastoralists the notes on plant communities would be brief and simple. The methods are certainly not without drawbacks. but do provide a means to get individual herders to look more closely at changes occurring and to better understand the penalty for overuse of the resource. 
Record keeping regarding livestock production should also be part of any rangeland livestock production system. Changes in animal production and costs/profits associated with the livestock operation will provide information to determine the efficiency of the operation and help identify constraints and limitations.

\section{Monitoring by the Department of Natural Resources}

Monitoring by the Department of Natural Resources should assess rangeland/pasture conditions by using more refined measurements regarding the ability of the site to produce resource values. The complexity of rangeland ecosystems often makes the interpretation of current conditions difficult, especially in considering natural variation. Therefore, I would propose a qualitative procedure that examines different ecological processes, including the water cycle, energy flow, and nutrient cycle. I believe the Department of Natural Resources should also utilize the same methodology as pastoralists to determine if those measurements are meeting objectives. Methodology of monitoring procedures should be adjusted for different areas, but the general aspects will be similar between sites.

An example of simple hypothetical degradation classification system is presented in Table 9. However, there has been considerable research into attributes and indicators of rangeland health and these should be included as training for personnel in the Department of Natural Resources. A more detailed rangeland health table is shown in Table 10.

The steps of developing a monitoring plan are based on management and monitoring objectives. In the first year, the Department of Natural Resources should initiate six steps in developing a monitoring program; many of these steps will have been part of the integrated management plan.

1. Define/refine management and monitoring objectives.

2. Stratify land into monitoring units (areas with similar characteristics).

3. Assess current status. Identify threats and opportunities. Develop/modify management strategy based on predicted changes.

4. Select monitoring indicators, number of monitoring plots, measurement and measurement firequency.

5. Select monitoring locations.

6. Establish monitoring plots (can be as simple as photo plots to detailed vegetation plots) and record long-term data (baseline). 
How often plots are re-measured will depend on time. money, and the need for intensive monitoring; however, some monitoring by pastoralists and/or resource managers should be attempted on a yearly basis. Management can be adjusted based on monitoring results using adaptive management principles.

Table 9. A degradation classification of vegetation of a temperate mountain meadow ecological site*.

Heavily Degraded Pasture. A mountain-steppe pasture is classified as heavily degraded if it has the following characteristics:

1) Previously dominant perennial species lave been replaced by less productive and often annual species.

2) Vegetation per unit of area of grassland is below $20 \%$.

3) The average height of grasses per unit area is less than $10 \mathrm{~cm}$.

4) The dry matter production is less than $300 \mathrm{~kg} / \mathrm{ha}$ per annum.

Moderate Degraded Pasture. A mountain-steppe pasture classified as moderately degraded will have the following characteristics.

1) Annual/less productive plants are common on the site.

2) Vegetation coverage per unit area range between $20 \%$ and $40 \%$.

3) The average grass height is $10 \mathrm{~cm}$ to $15 \mathrm{~cm}$.

4) The average dry matter production is between 300 and $500 \mathrm{~kg} / \mathrm{ha}$.

Lightly Degraded Pasture. A mountain-steppe pasture is classified as lightly degraded if it las the following characteristics.

1) The average vegetation coverage per unit area is greater than $40 \%$ to $50 \%$.

2) The average height of grasses is between 15 and $20 \mathrm{~cm}$.

3) The average dry matter production is greater than 500 to $700 \mathrm{~kg} / \mathrm{ha}$.

Non-Degraded Pasture. A mountain-steppe pasture is classified as non-degraded if it has the following characteristics.

1) The average vegetation coverage per unit area is greater than $50 \%$.

2) The average height of grasses is greater than $20 \mathrm{~cm}$.

3) The average dry matter production is greater than $700 \mathrm{~kg} / \mathrm{ha}$.

* A hypothetical example of a simple degradation procedure to illustrate methodology. 
Table 10. An example of a rangeland health evaluation summary form where a site is compared to a reference site (descriptors not shown).

Descriptors/Rating Classes

\begin{tabular}{|c|c|c|c|c|c|}
\hline Indicators & $\begin{array}{l}\text { Mostly } \\
\text { Disagree }\end{array}$ & $\begin{array}{l}\text { Moderately } \\
\text { Disagree }\end{array}$ & $\begin{array}{l}\text { Intermediate } \\
\text { Agreement }\end{array}$ & $\begin{array}{l}\text { Moderately } \\
\text { Agree }\end{array}$ & $\begin{array}{l}\text { Mostly } \\
\text { Agree }\end{array}$ \\
\hline \multicolumn{6}{|l|}{ 1. Rills } \\
\hline \multicolumn{6}{|l|}{ 2. Water Flow Patterns } \\
\hline \multicolumn{6}{|l|}{ 3. Pedestals or Terracettes } \\
\hline \multicolumn{6}{|l|}{ 4. Bare Ground } \\
\hline \multicolumn{6}{|l|}{ 5. Gullies } \\
\hline \multicolumn{6}{|l|}{ 6. Wind Scoured Areas } \\
\hline \multicolumn{6}{|l|}{ 7. Litter Movement } \\
\hline \multicolumn{6}{|l|}{ 8. Physical \& Chemical Soil Crusts } \\
\hline \multicolumn{6}{|l|}{ 9. Soil Surface Organic Matter } \\
\hline \multicolumn{6}{|l|}{$\begin{array}{l}\text { 10. Plant Community Composition \& } \\
\text { Distribution-Relative to Infiltration and } \\
\text { Runoff }\end{array}$} \\
\hline \multicolumn{6}{|l|}{ 11. Compaction layer } \\
\hline \multicolumn{6}{|l|}{ 12. Plant Functional/Structural Groups } \\
\hline \multicolumn{6}{|l|}{ 13. Plant Mortality } \\
\hline \multicolumn{6}{|l|}{ 14. Litter Amount } \\
\hline \multicolumn{6}{|l|}{ 15. Annual Production } \\
\hline \multicolumn{6}{|l|}{ 16. Noxious \& Invasive Plants } \\
\hline \multicolumn{6}{|l|}{$\begin{array}{l}\text { 17. Perennial Plant Reproductive } \\
\text { Capability }\end{array}$} \\
\hline \multicolumn{6}{|l|}{ Indicator Summary } \\
\hline \multicolumn{6}{|l|}{ Soil/Site Stability (Indicator 1-11) } \\
\hline Biotic Integrity (Indicator 9, \& 11-17) & & & & & \\
\hline
\end{tabular}

Comments on Indicator(s): 


\section{Capacity Development}

There is an urgent need to strengthen institutional capacity to lead Afghan's efforts in better rangeland management. The Department of Natural Resource"s national office in Kabul will need to direct professionals at the provincial level who will then direct staff throughout their province, district, sub-district, and village level. The national office will be responsible for ensuring quality national resource professionals in the field and will ensure that national goals are met. This will require training. improved facilities, better equipment, and time. Rangeland resource managers must have a strong understanding of rangeland ecology (including interaction of plant and animal communities with physical characteristics), plant physiology, animal nutrition and livestock management. hydrology and soils, and methods of inventory and monitoring procedures (including determination of rangeland condition). methods of rangeland improvements restoration/rehabilitation. and a knowledge of integration of intensive systems with extensive systems. I did not determine facility or equipment needs while in country: although, it is known that are significant needs for computers and software, vehicles. offices, and other basic inventory and monitoring equipment. I will stress capacity development from an education perspective in this section. both short-term and long-term education, to strengthen the Department of Natural Resources. The challenges in resource management are great; however, if we can improve capacity through training and education Afghans will be able to solve many of their natural resource problems. Educational opportunities (workshops) can supply participants with training materials and other bulletins and guides could be developed during workshops.

\section{Short-Term Education Opportunities}

It is apparent that there is an immediate need for workshops that provide basic information to rangeland managers. These workshops/training programs should be taught in Kabul as intensive short courses using Afghan and foreign resource specialist. It is unknown if there are Afghan professional natural resource managers that may be willing to actively participate in training programs and possibly with developing other programs in the Department of Natural Resources. The initial short courses or workshops should be in basic range management, but should also stress multiple-use. Initial topics covered should be plant and site identification, rangeland ecology, rangeland inventory and monitoring, rangeland animal nutrition and livestock production. range improvement and restoration, and rangeland planning. 
Following the short-courses resource managers would have some basic knowledge in developing plans to ensure resource values and should participate in pilot projects to develop natural resource management plans.

Development of Guides and Management Information. As stated previously, one product of the workshops would be documents on the various subject areas. Over time these could be developed to be more specific for Afghanistan by the extension service and researchers within MAAHF or by the university faculty.

Development of Range Management and Plant Books. A text book on Afghanistan rangeland management is suggested for students and professionals. Plant books identifying important forage species, rehabilitation species, common species, poisonous species, and characteristics to improve plant identification skills should be developed. It is likely that these texts should be done through the University.

\section{University and Graduate Training}

To continue to improve capacity of natural resource management in Afghanistan some of the brightest students in natural resource management should receive education outside the country to develop a broader and more diverse skill set. This training may be initial university education or graduate training for some members of the Department of Natural Resources. University training should be provided by scholarship or grants. These individuals, on returning to Afghanistan, will be able to train other district staff or work in research or extension to improve the Department of Natural Resources.

\section{Pilot Project Development}

As stated previously, each of the 5 strategies I listed for providing better resource management are interrelated. One way to illustrate these strategies is through pilot project areas. A number of pilot projects are in the early planning stages and should be opportunities to provide opportunities to illustrate the various strategies. These project areas could also be important to demonstrate methodologies and as such are excellent educational opportunities for participants. 


\section{Summary}

I have briefly described a general rangeland policy and provided brief outlines of strategies to achieve the policy. The rangeland policy will acknowledge the value of rangelands to the national economy for producing not only livestock products, but as watersheds, wildlife habitat (biodiversity), carbon sequestration, open space and aesthetic values. The rangeland policy will conserve (provide for sustainable uses) rangelands for future generations and provide procedures that balance local community(s) needs with national expectations. In management of State owned rangelands collaborative management will be stressed to ensure reduced management costs to the government and better management of the resource. All Ministries involved in natural resource management (for example MAAHF and MIRWE) and those involved with rural peoples and nomadic peoples (for example MRRD and MFTA) will be stakeholders in rangeland policy and strategies and will interact in setting policies and strategies. However, it is the Department of Natural Resources (formerly Department of Forestry and Rangelands) that should be the lead agency in directing rangeland policies and strategies.

The strategies or programs suggested for improving rangeland management are: (1) Rangeland Inventory and Classification: (2) Drought Preparedness and EWS; (3) Integrated Natural Resource Management Planning: (4) Rangeland Monitoring: and (5) Capacity Development (education and training). All of the strategies are interrelated and will be ongoing programs directed by the Department of Natural Resources. They are only briefly described as these programs should be developed and expanded with coordination with the Department of Natural Resources. Each of the programs will also require institutional capacity development through training and education, a strategy in itself, and likely the most important strategy. In order to demonstrate or "tie" these five strategies together I propose the development of a number of pilot projects that would initiate these different programs. I have not suggested locations, or selection criteria for different pilot project areas, but only suggest that pilot projects would be valuable for training and in providing additional information to allow for future planning endeavors. 


\section{Task H: Literature Cited}

Asian Development Bank. 2004. National Programme Framework for Community Forestry and Range Management, Summary Report. Technical (Ta No:3874-Afg), Component lb-2. Technical Assistance for Agricultural and Natural Resource Management and Planning. Kabul, December 2004.

Favre, R. 2005. Interface between state and society in Afghanistan: Discussion on key social features affecting governance, reconciliation and reconstruction. 27th January 2005. Kabul. $18 \mathrm{p}$.

Fisher, R.J. 1965. Collaborative management of forests for conservation and development. IUCN/WWF. 66p.

MAAHF (Ministry of Agriculture. Animal Husbandry, and Food). 2005 (November). Master plan for agriculture, animal husbandry and food. Kabul, Afghanistan. 389 p.

Richard, C. and D. Miller. 1998. Grazing commons of the Hindu-Kush Himalaya and the Tibetan Plateau: Constraint or opportunity? Conference on Strategic Considerations on the Development of Central Asia, Urumci, Xinjiang. China, September 13-18.

Weijer, de F. 2005. Towards a pastoralists support strategy. Draft document, October 2005. Kabul. 61 p. 


\section{APPENDICES}

\section{Appendix 1. FAO archives, Afghanistan 1960-96}

(Source:http://www.fao.org/world/afghanistan/arch_en.htm)

Survey of Land and Water Resources - Plans of Operation 1960

Amended Plan of Operation United Nations Special Fund Project in Afghanistan Survey of Land and Water

Resources 1964

Survey of Irrigation Possibilities in the Hari Rud and Upper Kabul River Basins

Demonstration and Training in Forest and Range Improvement 1967

Training and Demonstration of Animal Health and Animal Husbandry 1967

Programme on Agricultural Credit and related services through Cooperatives in Afghanistan 1967

KUNDUZ-KHANABAD Irrigation Feasibility Study 1969

Programmes on Agricultural Credit and related Services through Cooperatives in A fghanistan 1970

Assistance to Rural Broadcasting 1971

Project on Agricultural Credit and Related Services through Cooperatives in A fghanistan (Plase II) 1973

National Parks and Utilization of Wildlife Resources (Phase II) 1975

Improvement of Services for Agricultural Machinery 1976

Animal Health (Phase II) 1977

Training Assistance for the establishment of the Agro-Chemical and Veterinary Medicines Division of the Afghan Fertilizer Company (AFC) 1977

Kunar Forestry Development Demonstration 1977

Establishing Processing and Marketing Capacities for Fluid Milk in Kabul 1977

Development of Communication in the Provinces of Wardak. Logar, Kunduz and Herat 1977

Strengthening the Government Capability in Planning and Implementation (Phase II) 1978

Irrigation Development in the Kunar Region 1978

National Parks and Wildlife Management 1978

National Parks and Wildlife Management (Phase III) 1978

Project on Agricultural Cooperatives and Credit in Afghanistan - PACCA, (Phase III)1981

Strengthening Plant Protection Services 1978

Status of Alpine Rangelands in Central Afghanistan with Special reference to the Ajar Valley Wildlife Reserve 1978

Revival of Veterinary Vaccination Campaign group 1978

Kunar Wood Utilization Development and Demonstration 1978

Assistance to Forestry \& Watershed Development 1979

Training in Seed Production Terminal Statement 1979

Biogas and Blue green Algae Technologies, Demonstration and Training 1979

Supply of Foundation Wheat Seed 1979

National Parks and Wildlife Management Afghanistan Project Findings and Recommendations 1980 
Analysis of Afghanistan's Rangelands and Strategies for Sustuinable Management, January 5, 2006.

Kunar Wood Utilization Development and Demonstration Terminal Statement 1978

Revival of Veterinary Vaccination Campaign group Terminal Statement 1980

National Parks and Wildlife Management - Afghanistan. A Contribution to a Conservation Strategy-volume I. Appendixes 1981

National Parks and Wildife Management - A fghanistan. A Contribution to a Conservation Strategy-volume II. Appendixes 1981

Project on Agricultural Cooperatives Training in Afghanistan (PACTA) 1981

Assistance to the Faculty of Veterinary Science 1981

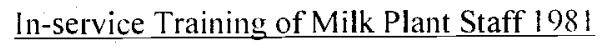

Seed Production \& Training 1982

Agriculture Development 1982

Strengthening the Central Diagnostic Laboratory and Department of Veterinary Services 1982

In-service Training of Milk Plant Staff Terminal Statement 1983

Workshop in Hungary on Increased Agricultural Production through Small and Large-Scale Farming 1983

Training in Agricultural Censuses and Surveys 1984

Training in Agricultural Censuses and Surveys Terminal Statement 1984

Assistance to Agricultural Cooperative Sector 1985

Improvement of Services for Agricultural Machinery 1985

Dairy Development Study 1985

Assistance in the Establishment of Two Model Agricultural Production Cooperatives Terminal Statement 1986

Strengthening the Planning Capability in the Ministry of Agriculture and Land Reform 1986

Seed Production \& Training (Phase II) 1987

Rainbow Trout Culture in Qargha Fish Farm Kabul 1987

Assistance to the Faculty of Veterinary Science (Phase II) 1987

Ecological \& Vegetation Mapping 1983

Assistance to Agricultural Cooperative Sector Terminal Statement 1987

Rehabilitation of the Kabul Milk Plant 1987

Training Assistance to the Data Collection and Mapping Centre 19

Research in Cereals and Pulses Improvement (Preparatory Plase) 1987

Apiculture Development 1987

Agricultural Development Bank 1987

Strengthening of Forestry Department (Phase II) 1987

Sericultural Development. Research and Training 1988

Development of Livestock Diseases Surveillance and Control Planning (Phase I) 1988

Strengthening Agricultural Construction 1988

Rehabilitation of the Kabul Milk Plant Terminal Statement 1991

Utilization of Remote Sensing for Inventory and Monitoring of Agricultural Land 1992

Coordination of UN Agricultural Rehabilitation Programmes in Afghanistan 1994

Rehabilitation of Veterinary Clinics \& Provision of Related Inputs 1995 
Appendix 2. FAO reports available from ACBAR.

Title

$\underline{\text { Skill of fisheries [Dari] / Khalilullah Forogh }}$

Livestock development for food security in Afghanistan /

Food \& Agriculture Organisation

Planning and management for sustainable coastal aquaculture development / FAO, GESAMP
Author

Forogh,

Khalilullah

$\mathrm{N} / \mathrm{A}$

$\mathrm{N} / \mathrm{A}$

Report of the nineteenth session of the coordinating working party on fishery statistics, Noumea, new Caledonia, 10-13 July $2001 /$ Food and Agriculture Organization of the United

Nations

Manual for training of extension workers and farmers:

alternatives to methyl bromide for soil fumigation / R. Braga Braga, $R$ ... [et.al]

Technical report seed component activities (01 January 2000 - 30 June 2000)/N. S. Tunwar

Tunwar, N. S. Seed Distribution

Manual of procedures for the implementation of the Asia

regional technical guidelines on health management for the

responsible movement of live aquatic animals / Food and

Agriculture Organization of the United Nations, Network of

Aquaculture Centres

A Millennium free from hunger / Food and Agriculture

Organization of the United Nations

$\mathrm{N} / \mathrm{A}$

Food Relief

Report of the conference on aquaculture in the third millennium Bangkok. Thailand, 20 - 25 February $2000 /$

Food and Agriculture Organization of the United Nations

Report of the AD HOC meeting on management of deepwater fisheries resources of the southern Indian ocean Swakopmund, Namibia, 30 May - 1 June 2001 / Food and Agriculture Organization of the United Nations

Food for seed: a new collaborative approach for food security/N. S. Tunwar

Reform and decentralization of agricultural services: a policy Smith,

framework / Lawrence D. Smith

Lawrence D.

Agriculture - Planning

Agricultural rehabilitation in southern and eastern

Afghanistan: prepared as of March 31 th 1995 volume I - III / prepared by Anthony Ralph Fitzherbert

The FAO programme in Afghanistan 1988 - 1997 / Jacques

Diouf

Report to the government of Afghanistan on farm implements and small powered machines / H.H. Duchmann
Fitzherbert,

Anthony Ralph Agricultural Projects

Diouf, Jacques Agricultural Development
Projects

Duchmann, H. Agricultural Development $\mathrm{H}$. Projects 
Analysis of Afghanistan's Rangelands and Strategies for Sustainable Management, January 5, 2006.

ProMlS design project phase $1 /$ / Food and Agriculture Organization of the United Nations

Plant protection in Faryab province: a socio-economic assessment / Mervyan T. Patterson, Noor Agha Akbari

Livestock development for food security in Afghanistan: Database \& GIS section / Food and Agriculture Organization

Technical report seed component activities (May 1998 April 1999)/N. S. Tunwar

Fish stock assessment manual / Emygdio L. Cadima

Guidelines for participatory nutrition projects in A fghanistan [English, Dari]/FAO

Evaluation mission of the FAO/UNDP A fighanistan agriculture programme / FAO, UNDP

TCE - Emergency relief and rehabilitation activates / FAO

Afghanistan agricultural strategy: promotion of agricultural rehabilitation and development programmes for Afghanistan, final draft / prepared by Food and Agriculture Organiztion of United Nations

Integrated crop and food production in Afghanistan: an acount of the achievements of the AFG/94/002 programme 1995-1997 and opportunities for 1997-1999/Food and Agriculture Organisation of the United Nations

Construction materials [Dari] / Abdul Haq Zia

Water harvesting [Dari] / Saved Sharif Shobair

The Daily time profile of Brahui women, Balochistan province / Marilee Kane

The Credit programme and income generating activities of Brahui women, Balochistan province / Marilee Kane

Brahui women's indigenous knowledge of medicinal plants, Balochistan province / Marilee Kane ... [et al.]

Land cover map: Islamic State of A fghanistan [map] / Food and Agriculture Organization of the United Nations, Afghan N/A Geodesy and Cartography Head Office.-- Scale 1:250,000

Afghanistan 1:250,000 photomap [map]/ Food and Agriculture Organization of the United Nations, A fghan Geodesy and Cartography Head Office.-- Scale 1:250.000
$\mathrm{N} / \mathrm{A}$

Program Management Information System (Promis)

Patterson, Agircultural Estimating Marvyn T And Protecting

N/A Livestock

Tunwar, N. S. Seed Distribution

Cadima,

Emygdio L.

Fish Stock Assessment

N/A Nutrition

N/A Agricultural Projects -

Evaluation

Rehabilitation

Agricultural Development Projects

N/A

Crops

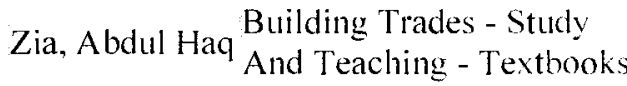

Shobair, Sayed

Sharif

Water Storage

Kane, Marilee $\begin{aligned} & \text { Women In Community } \\ & \text { Development - Baluchistan }\end{aligned}$

Kane, Marilee

Women In Community Development - Baluchistan

Kane, Marilee

Medicinal Plants -

Baluchistan

Agricultural Surveys -

Maps

$\mathrm{N} / \mathrm{A}$

Agricultural Surveys -

Maps 
Report of the livestock identification mission to Afghanistan by T.A. Jones and D. McFarlane

Jones, T.A. Livestock

The FAO programme in Afghanistan, 1988 - 1997/ Food and Agriculture Organization of the United Nations

N/A

Un Agencies - Reports

List of library publication / Food and Agriculture

Organization of the United Nations, Livestock Development N/A

for Food Security in A fghanistan

Technical report on cereals and food legumes varietal performance in Afghanistan / N. Wassimi

Wassimi, N. Cereals

Recommendation of barley lines to ACBAR Agriculture Sub-committee for approval as new barley varieties for Afghanistan / by N. Wassimi and A.R. Manan

Recommendation of rice lines to ACBAR Agriculture Subcommittee for approval as new rice varieties for A fghanistan by N. Wassimi and A.R. Manan

Wheat varieties for Afghanistan : report to $F A O$ representative. Islamabad, Pakistan / prepared by Eugene E. Saari.

A Question of gender: reflections from a livestock project perspective, working paper no. 1/98/ Karen Iles

Wassimi. N. /

Manan, A.R. Barley

Wassimi, N.: Rice

Manan, A.R.

Bibliography

Saari, Eugene

E.

Wheat - Varieties

lles, Karen Gender

Livestock development for food security in A fghanistan: project performance evaluation report, January 1998 -

December $1998 /$ T. J. Barker

Livestock developinent for food security in A fghanistan / FAO, UNDP

Activities of Kuchi survey team, working paper no. 1/99! T.J. Barker, O. Thieme ... [ et al.]/

Food security through sustainable crop producation in Afghanistan / FAO, UNDP

Afghanistan agricultural strategy: food security strategy for rural areas / FAO

Generating income from beekeeping in Afghanistan: a guide for beekeepers, farmers and extension workers [English, Dari] UNDP, FAO

Range management and animal husbandry practices in Afghanistan of demonstration and training in forest and range improvement project / by O.N. Alpay

Poultry guide [Dari] / Mohammad Haroon Nassar

The development of veterinary services in Afghanistan 1986 - 2000: livestock development for food security in Afghanistan / Terence J. Barker, A. Baqi Mehraban

Barker, T.J. Livestock Productivity

$\mathrm{N} / \mathrm{A}$

Livestock Productivity

Barker, T.J./ Nomads

Thieme, O. Nomads

N/A Food Crops

N/A

Food Supply - Surveys

N/A Honeybee

Alpay, O.N. Range Management

Nassar

Mohammad Poultry

Haroon

Barker,

Terence J.
Veterinary 
Food security through sustainable crop production in Afghanistan, technical report: results and findings of horticultural field survey in Seventy-Nine districts of

\section{Afghanistan / FAO}

Second technical report on cereals and food legumes crop varieties selection in Afghanistan 1998-1999/N. Wassimi

FAO/WFP Crop and food supply assessment mission to Afghanistan /FAO/WFP

Six monthly report seed component activities (July 1999 December 1999)/ N. S. Tunwar

Report to the Government of Afghanistan on small agricultural implements / by W. Sommeraurer.

Irrigation water management: maintenance and repair of irrigation canals [Dari] / Sayed Sharif Shobair

Farmer training package livestock production: livestock feeding, livestock housing, management of young stock, parturient cows \& ewes, livestock breeding, milking / FAO

Farmer training packages backyard poultry production: poultry feeding, poultry housing, poultry diseases, poultry breeding / FAO

Farmer training packages livestock diseases: diseases treated by farmers, diseases for vaccination, Zoonotic diseases / N/A $\underline{\mathrm{FAO}}$ utilization of remote sensing for the inventory and monitoring of agricultural land in Afghanistan / FAO, UNDP

Summary of recommendations [on wheat] / prepared by Eugene Saari.

Saari, Eugene

E.

Targeting for nutrition improvement: resources for advancing nutritional well-being / Food and Argriculture Organization of the United Nations

$\Lambda$ gricultural research policy and development / Vernon W. $\underline{\text { Ruttan }}$

$\mathrm{N} / \mathrm{A}$

Sommeraurer

W.
Provincial landcover atlas of Islamic State of Afghanistan:

Wassimi, N. Cereals

Crops

Tunwar, N. S. Seed Distribution

Agricultural Implements

Shobair, Sayed Irrigation - Maintenance Sharif And Repair

N/A Farmers - Training

N/A Poultry - Diseases

Farmers

Agriculture - Afghanistan Atlases

Wheat

N/A Nutition

Ruttan, Vernon Agricultural Development W. Projects

Poore, M.E.D. Forests And Forestry

The Ecological effects of eucalypts / by M.E.D. Poore and C $\underline{\text { Fries }}$

A Preliminary management plan for the Ajar valley wildlife reserve / prepared by Christopher C. Shank, Ronald G. Petocz and Khushal Habibi

Shank,

Christopler C. Animals

Agricultural development and nutrition / edited by Arnold Pacey and Philip Payne

Pacey, Arnold (ed.)

Food Crops

Report: A fghanistan forestry consultancy

UNO/AFG/102/UNA / Peter Kaern
Kaern, Peter

Forests And Forestry Konar 
Animal health and livestock production programme in

Afghanistan: strategy for cost recovery on vaccines / T.J. Barker

Basic elements of trade in Afghanistan [Dari] / Mohammad lshaq Meskeenmal, compiled by Mohammad Haroon

Integrated crop and food production in Afghanistan: orchard and vineyard integrated production and protection consultancy, report of second mission to define a uniform technical packagage for fruit culture \& train national. / by Daid W. Doolan

Afghanistan agricultural strategy development workshop: workshop discussion report, Agricultural University Peshawar, 30-31 October 1996/FAO

Beginning surveying [Dari]/ Abdul Haq Zia

Rehabilitation of informal irrigation system in A fyhanistan, design manual [Dari] / Ian McAllister Anderson, translated by Abdul Haq Zia, Sayed Sharif Shobair

Gabion and its use [Dari]/Sayed Sharif Shobair

FAO publications catalogue 1995 / Food and Agriculture Organization

Audio-visual aids for cooperative education and training / by C. N. Botham

Survey of land and water resources: A fghanistan, general report / Food and Agriculture Organization

Restoration of the Nemla garden (interior irrigation system) / prepared by A. Hasib Latify prepared by A. Hasib Latify

Cereal seed technology: a manual of cereal seed production, quality control, and distribution / edited by Walther P. Feistritzer

Agricultural price policies: issues and proposals / Food and Agriculture Organization of the United Nations

Conceptual frame work relating to Afghan agricultural rehabilitation

Irrigation development in Hari Rud valley, Herat, Afghanistan: reconnaissance report/by M. Q. Naimi

Nemla garden in Khugyani district, Nengarhar province: technical survey / Multi Activity Rural Rehabilitation Foundation

FAO programme for the rehabilitation of A fighanistan: rehabilitation of informal irrigation systems in Afghanistan.
Barker, T.J. Livestock Productivity

Meskeenmal,

Mohammad Foreign Trade

Ishaq

Doolan, David

W.

Orchards

N/A

Agricultural Development Projects

Zia, Abdul Haq $\begin{aligned} & \text { Surveying - Study And } \\ & \text { Teaching }\end{aligned}$

Anderson, Ian Irrigation
McAllister

Shobair, Sayed

Sharif

Gabions

N/A Agriculture - Bibliography

Botham, C.N. Education - Teaching Aids

N/A Land Use

Latify, Abdul Gardens - Nangarhar -

Hasib Surveys

Feistritzer,

Walther P.

Seeds

N/A

Agricultural Price Supports

$\mathrm{N} / \mathrm{A}$

Reconstruction. Rural Planning

Naimi,

Mohammad Irrigation - Herat

Qaseem

N/A

Gardens - Nangarhar -

Surveys

Anderson, lan Irrigation
McAllister 
design manual/ by lan McAllister Anderson

Report on the Afghan Pamir: part 1, ecological reconnaissance / by Ronald G. Petocz

Report on the Afghan Pamir: part 2, biology of Marco Polo sheep / by Ronald G. Petocz ... [et al.]

Report on the Afghan Pamir: part 3, a management plan for the big Pamir wildlife reserve / by Ronald G. Petocz

The Mammals of Afghanistan: their distribution and status / by Khushal Habibi

Status of alpine rangelands in central Atghanistan with special reference to the Ajar valley wildlife reserve / prepared by John Y. Larsson

The Trade in wild animal furs in Afghanistan / prepared by Willem F. Rodenburg

A Preliminary study of lake Hashmat Khan with recommendations for management / prepared by Abdul Rahim, John Y. Larsson

A Strategy for the establishment and development of Bande Amir national park / prepared by Christopher C. Shank and

Management plan for Ab-i-estada and Dashte Nawar flamingo and waterfowl sanctuaries / prepared by Christopher C. Shank and Willem F. Rodenburg Ecological reconnaissance of westem Nuristan with recommendations for management / prepared by Ronald G. Petocz and John Y. Larsson

Tree growing by rural people / FAO
Petocz, Ronald Badakhshan - Wakhan G. Pamir

Petocz, Ronald Badakhshan - Wakhan G. Pamir

Petocz, Ronald Badakhshan - Wakhan G. Pamir

Habibi,

Khushal Mammals

Larsson, John

Y.

Animals

Rodenburg, Willem F.

Fur Trade

Abdul Rahim Hashmat Khan, Lake

John Y.

Larsson Shank, Bande Amir

Christopher C.

Shank,

Christopher C. Flamingos

Petocz, Ronald

G.

Birds

N/A

Forests And Forestry

Forests And Forestry

A Guide to forest seed handling:
tropics / compiled by R.L. Willan

(comp.)

Forests And Forestry

Forestry for local community development / FAO Forestry

Department with the assistance of the Swedish International N/A

Development Authority

Fuelwood supplies in the developing countries / by M.R. de Montalembert and J. Clement

de Montalembert, M.R.

Forests And Forestry Developing Countries

Appropriate technology in forestry: report of the consultation on intermediate technology in forestry held in New Delhi N/A and Dehra Dun, 18 October - 7 November $1981 /$ FAO

Simple technologies for charcoal making / FAO Forestry Department
Forest Management Developing Countries

N/A Fuel 
Beekeeping in Asia / by Pongthep Akratanakul

Honeybee diseases and enemies in Asia: a practical guide / by Pongthep Akratanakul

S.M.U. mission to Kunar: August 21 st to 28 th 1990 , draft report / by A.R. Fitzherbert

Monitoring mission to Paktia, July II to 16th 1990, draft report / prepared by A.R. Fitzherbert

Quality population: our hope for survival / Population

Education Through Rural Agricultural Development

Networks

Tropical and sub-tropical apiculture / FAO

Programme for rehabilitation of Afghanistan agriculture, provision of fruit trees 1990-91: consultant's report / prepared by J. Cartwright.

Purchase of fruit trees and poplars for the $1989 / 90$ planting season / by J. Cartwright

Terminal report on the (FAO/UNHCR/WHO) mission to Paktia province of A fghanistan / by Sayed Malıboob; submitted to FAO.

A Manual for planting of poplar in A fghanistan / J.C. Tandon

Report to the Government of Afghanistan on soil fertility and fertilizer use / based on the work of P.M. Tamboli.

Conceptual frame work and proposed strategy: Afglian agricultural rehabilitation / Raymond E. Fort
Akratanakul, Pongthep

Bee Culture - Asia

Akratanakul,

Pongthep

Fitzherbert,

A.R.

Fitzherbert,

A.R.

Bee Culture - Asia

Agricultural Surveys Konar

N/A

Agricultural Surveys -

Paktya

$\mathrm{N} / \mathrm{A}$

Bee Culture

Cartwright, Jim Fruit Trees

Cartwright, Jim Fruit Trees

Sayed

Mahboob Paktya

Tandon, J.C. Tree Planting

Tamboli, P.M. Fertilizers And Manures

Fort, Raymond Reconstruction, Rural -

E. Planning

$\begin{array}{ll}\text { Irrigation water management: crop water requirements [Dari] Shobair, Sayed Irrigation - Management } \\ \text { Sayed Sharif Shobair } & \text { Saharif }\end{array}$ Sayed Sharif Shobair

Affects of deep wells on groundwater resources in

Afghanistan [Dari, English]/ Sayed Sharif Shobair

Shobair, Sayed Water Resources

Sharif Development

$\underline{\text { Standardization in Afghanistan [Dari] / Sayed Sharif Shobair }} \begin{aligned} & \text { Shobair, Sayed Standards, Engineering } \\ & \text { Sharif }\end{aligned}$

Consultancy report on poplar cultivation in Afghanistan /

J.C. Tandon

Tandon, J.C. Poplars

Ecological classification of Afghanistan [Dari] / Sayed Amir $\underline{\text { Shah Hassanyar }}$

Hassanyar,

Sayed Amir Ecology

Shah

Hassanyar,

Ecology of A fghanistan [Dari] / Sayed Amir Shah Hassanyar Sayed Amir

Shah

Agricultural Ecology 
Analysis of Afghanistan's Rangelands and Strategies for Sustainable Management, January 5, 2006.

Ecology of the central regions [Dari] / Sayed Amir Shah Hassanyar Sayed Noor Aga Hashemi

Agroecology: the scientific basis of alternative agriculture / Miguel A. Altieri

Practical ecology / David Slingsby and Ceridwen Cook
Hassanyar,

Sayed Amir Ecology

Shah

Altieri, Miguel

A.

Agricultural Ecology

Slingsby,

David

Ecology

Environmental education in the developing world / James V. Connor, James Ecology - Study And Connor.

$\mathrm{V}$.

Teaching 
Appendix 3. Other citations noted from other sources that should be reviewed for inclusion in vegetation and rangeland classifications.

Freitag. H., 1971. Die Naturliche Vegetation A fghanistan. In Vegetation: 22:285-344.

Freitag. H. 1971. Studies in the natural vegetation of Afghanistan. In: P.H. Davis. (ed.) Plant life of South-West Asia. Royal Botanic Garden. Edinburgh. pp. 89-106.

Hassanyar, Amir S., 1972. Ecology of A fghanistan. Kabul: Kabul University Press.

Hassanyar, Amir S., 1977. 'Restoration of Arid and Semiarid Ecosystems in A fghanistan. In .J. Environ. Conserv. 4(4): 279-301.

Hassanyar, Amir S., 1980. The Stability of Spruce Forests in Montane Ecosystems of Afghanistan'. In Proceedings of International Symposium. Bmo pp 210-220. Czechoslovakia: Publisher not given.

Hassanyar, Amir S. 1981. The Marco Polo Sheep. In Georg. Bull. (9-10).

Hassanyar, Amir S. 1985. Natural Forests of A fghanistan. Kabul: Kabul University Press.

Hassanyar, Amir S., 1987. A Survey of Environmental Legislation and Institutional Framework in Afghanistan'. In International Workshop on SACEP Environmental Legislation-January 15-16, 1987, New Delhi, India.

Hassanyar. Amir S. 1990. Arid Zones of Afghanistan in Perspective. In UNESCO Publ. Misc

Hassanyer, A.S. 1977. Restoration of arid and semi-arid ecosystems in Afghanistan. Env. Cons. $4(4)$.

ICIMOD (International Center for Integrated Mountain Development). 1995. A biodiversity profile of Afghanistan. In: Biodiversity Issues in the HKH. Regional Consultation on Biodiversity Assessment in the Hindu Kush-Himalayas. ICIMOD, Kathmandu, Nepal. See http:/www.icimod.org.np/focus/biodiversity/afgbio.htm

Kisra, S.D. 1967. Natural regions of Afghanistan. J.G. (Stellenbosch) 3(1): 27-31.

Kumler, K.L. 1969. Plant distribution on hills surrounding Kabul, Afghanistan. Transact. Illin. State Acad. Sci. 62 (2): 141-153.

Kyoto University. 1960-65. Result of the Kyota University Scientific Expedition to the Karakorum and Hindu Kush. 5 Volumes. Kyoto, Japan.

Lalande, P. 1967. Generalitee sur la vegetation du Safed-Koh et de son prolongment occidental. Bull. Soc. Hist. Nat. Touluse. 103: 297-304. (Generalities on the vegetation of Safed-Koh and its western extension). 
Lalande, P. 1968. Etakes A genevriers on Afghanistan. Conpt. Rend. Acad. So. Prarie. 267D: 503-504. (The juniper formation in Afghanistan.

Lalande. P. Generalitiee sur la vegetation du basin du Kaboul en Afghanistan. Trav. Lab. For. Toulouse. V(I,3 art. III):1-17. (Generalities on the vegetation of the Kabul basin in Afghanistan).

Lincheviski, I.A. 1946. The principal regularities in vegetation distribution of A fhanistan. Bot. Zh. Kyyiv. 183-218.

Lincheviski, I.A. and A.V Prozorovski. 1944. The vegetation of Afghanistan. Bot. Zhurn. 29; I14-123. (In Russian).

Lincheviski. I.A. and A.V Prozorovski. 1949. Basic principles of the distribution of the vegetation of Afghanistan. Kew Bull. 1949(2): 179-214.

McArthur. I.D. and G.N. Harrington. 1978. A grazing ecosystem in western Afghanistan. Proc. $\mathrm{I}^{\text {st }}$ Internat. Rangelands Congress. Denver, CO.

McArthur, I.D., Sayed, S. and M. Nawin. 1979. Rangeland livestock production in western Afghanistan. J. Arid Environments 2: 163-179.

Michels, A.A. 1959. The Kabul, Kunduz and Helmand valleys and the national economy of Afghanistan. Nat. Acad. Sci., National Research Council, Washington.

Nedialkov, S. 1973. Etude sur la classification ecologique de la vegetation legneus natural en Afghanistan. UNDP/FAO/67.

Nedialkov, S.T. 1978. Ecological areas of the forest tree and bush vegetation in Afghanistan. Goreskostopanska Nanka (Sofia) I5(2): 7I-89.

Nehr-Homji, V.M., Gupta, R.K. and H. Freitag. 1973. Bibliography on "Plant Ecology" in Afghanistan. Excerpta Botanica Sectio B Sociologica. 12: 310-315.

Neubauer, H.P. 1951. Die Pflanzengesellschaften Afghanistans. Ber. An das Kgl: Afghan. Kinisterium fur Landwirtschaft vom 19.195I. (The plant communities of Afghanistan).

Neabauer, H.F. 1954. Die Walder Afghanistans. Angew. Pfl. Soziol. Festscher. E. Aichinger. 1: 494-503. (The forests of A fghanistan).

Neabauer, H.F. 1954. Versuch einer Kennzeichnung der Vegetationeverhaltniese Afghanistans. Annln. Naturh. Mus. Wien. 60:77-113. (Attempt on the characterisation of the relationships in vegetation in Afghanistan). 
Pavlov, V.N. and I.A. Gubanov. 1983. Botanical-geographic peculiarities of mountain Afghanistan. In: Ecology and biogeography of Afghanistan. Moscow. pp. 54-75. (In Russian).

Pelt. J. N.. Hayon, J. C. \& Younos, H. C. 1965. Plantes médicinales et drogues de l'Afghanistan. Bull. Soc. Pharm. Nancy. 66: 16-61. (Medicinal and drug plants of Afghanistan)

Pelt, J.N. Hayon, J. C. \& Younos, M. C. 1968a. Sur la flore et la végétation d'une zone halophile steppique en bordure de l'A mou-Darya (A fghanistan). Compt. rend. Acad. Sc. Paris 267D: 505-508. (On the flora and vegetation of a halophytic steppe zone along the Amu Darya (Afghanistan))

Pelt, J. N., Hayon, J.C. \& Younos, M.C. 1968b. Sur la fore et la végétation des borde du lao Abi-Estada. Compt. rend. Acad. Sc. Paris. 267D: 1279-1282. (On the flora and vegetation of the banks of the Ab-i-Estada lake)

Pelt, J. N.. Hayon, J.C. \& Younos, M.C. 1969. Caractères écologiques et floristiques de deux halophiles d'Afghanistan. Vegetatio. 20: 307-328. (Ecological and floristical characteristics of two halophyllios of A fghanistan)

Pelt, J. N., Hayon, J.C. \& Younos, M.C. 1970a. La végétation d'une cuvette halophile du bassin de Bamian (Afghanistan Central). Compt. rend. Acad. Sci. Paris. 271D: 320-323. (The vegetation of a halophil basin in the Bamian Basin (Central Afghanistan))

Pelt, J. N., Hayon, J.C.\& Younos, M.C.1970b. La végétation de la Vallée d’Madjar (Afghanistan Central). Bull. Soc. bot. France. 117: 297-306. (The vegetation of the Ajar Valley (Central Afghanistan))

SCA (Swedish Committee for Afghanistan). 1990. The Agricultural Survey of Afghanistan: I ivestock. The I0th Report. SCA, Peshawar, Pakistan.

Shahrani, N.N. 1976. Kirghiz pastoral nomads of the Afghan Pamirs: A study in ecological and intra-cultural adaption. Ph.D. theses. University Microfilms American Arbor, Michigan. Order no. 77-620.

Rechinger, K. H. 1963a. Bericht über eine botanische Expedition nach Afghanistan. Anz. öst. Akad.Wiss. 100: 71-72. (Report on a botanical expedition to Afghanistan)

Rechinger, K.H. \& Koile, M. 1954-63. Symbolae Afganioae. Biol. Skr. I Labiatae 8(1), 1954: 2 Compositae 8(2), 1955; 3 Leguminoesae 9(3). 1957; Cruciferae, Rubiaceae,

Sorophulariaceae 10 (3), 1959; 5 Div. 13(4), 1963; 6 Descr. of plants coll. by $3^{\text {rd }}$ Danish Exp. to Central Asia 10(3), 1958, $191 \mathrm{p}$.

Rechinger. K.H. and Riedl, H. 1961-62. Zur Flora von Nord-Ost-Afghanistan. Annin naturh. Mus. Wien. 65: 29-37. (On the flora of northeastern Afghanistan). 
Sahab, A. (ed.) 1974. General atlas of A fghanistan. Sahab Geographic \& Drafting Institute. Teheran.

Salem, N.Z. and F.D. Mole. 1969. Soil geography and factors of soil formation in Afghanistan. Sci. 107(4) 289-295.

Singer, A. 1976. Problems of pastoralism in the Afghan Pamirs. J. Asian Affairs. V 63(new series v. VII) pt. II: 156-160.

Tapper, R. 1974. Nomadism in Afghanistan: asset or anachronism. In: Dupree and L. Albert (eds.). Afghanistan in the 1970s. Praeger

VARA/Cordaid. 2003. An assessment of econonic opportunities for Kuchi IDPs in Maywand and Panjway Districts.

Vegetation und Flora im Zentralen Hindukus (Afghanistan) VW Frey and W Probst TUBINGER ATLAS DES VORDEREN ORIENTS - SUPPLEMENT A3 109 pages, $12 \mathrm{col}$ plates, illus, tables, 10 maps. Ludwig Reichert Verlag (out-of-print).

Volk, O.H. 1951. Vegetationseindroucke in Afghanistan. 3:210-212. (Vegetation impressions in Afghanistan)

Volk, O.H. 1951. Klima und Pflanzenverbreitung in Afghanistan. 5-6. 422-433. (Climate and plant distribution in Afghanistan). 
Appendix 4. Policy agenda from Asian Development Bank, 2003.

\begin{tabular}{|c|c|c|}
\hline Subvetor & Pollog issue & Commants \\
\hline \multirow[t]{4}{*}{ 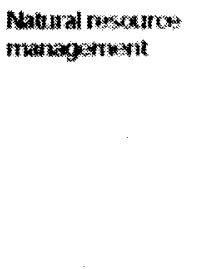 } & 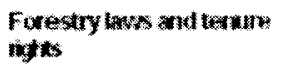 & 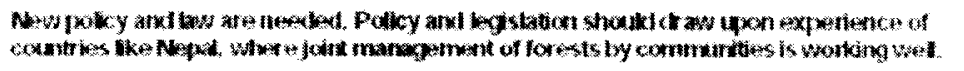 \\
\hline & $\begin{array}{l}\text { Moraxatersiod } \\
\text { Nominy }\end{array}$ & 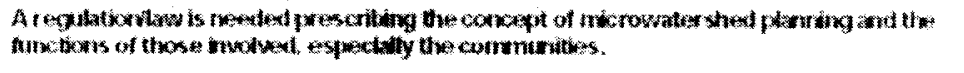 \\
\hline & Aurdoratay & 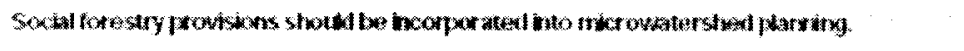 \\
\hline & Emiratenental protextica & 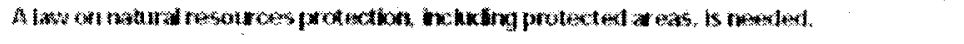 \\
\hline \multirow[t]{4}{*}{ 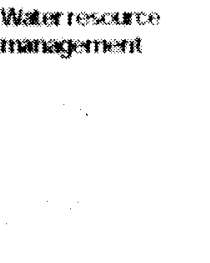 } & 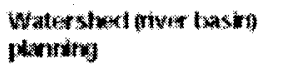 & 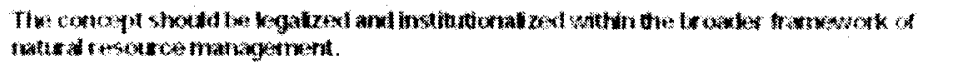 \\
\hline & Water aw & 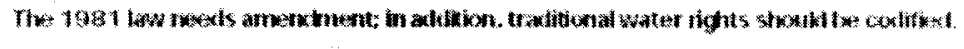 \\
\hline & Crounkwate thowon & 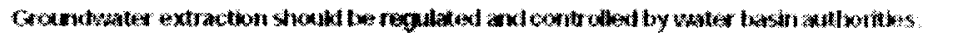 \\
\hline & 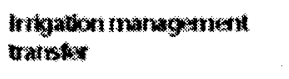 & 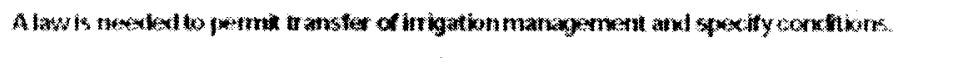 \\
\hline 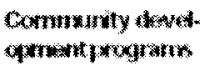 & 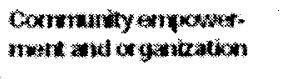 & 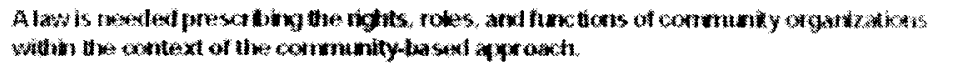 \\
\hline \multirow[t]{6}{*}{ Agraturescoss } & Agroumaltoma & 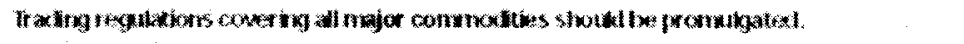 \\
\hline & Auralocopwatwer & 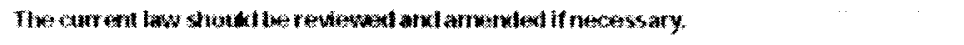 \\
\hline & 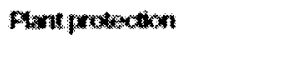 & 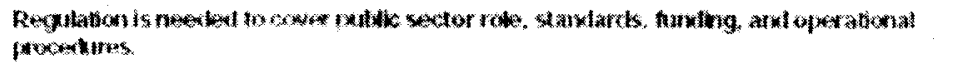 \\
\hline & S*wertaritan & 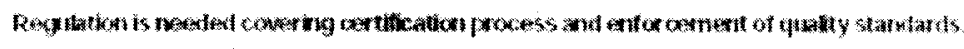 \\
\hline & Laxi teruma & 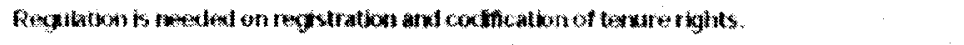 \\
\hline & 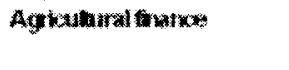 & 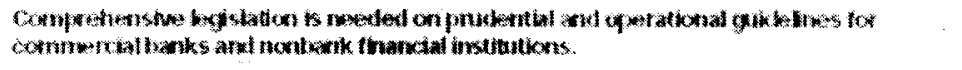 \\
\hline
\end{tabular}


Appendix 5. Mean annual precipitation of Afghanistan (from Afghanistan Information Management Service (AIMS)(http://www.aims.org.af/).

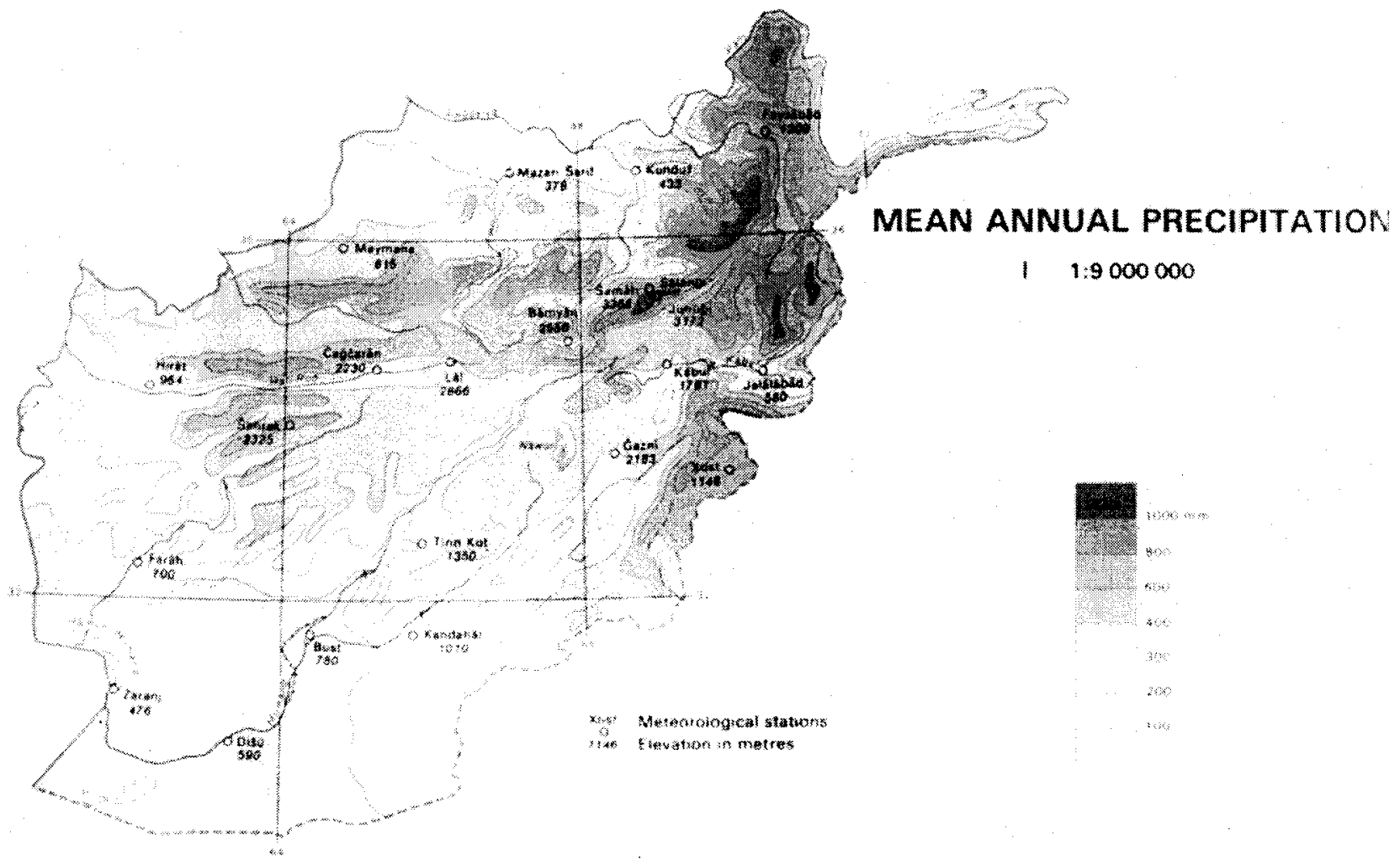


Appendix 6. Climatic regions of Afghanistan (from Afghanistan Information Management Service (AIMS)(http://www.aims.org.af/).

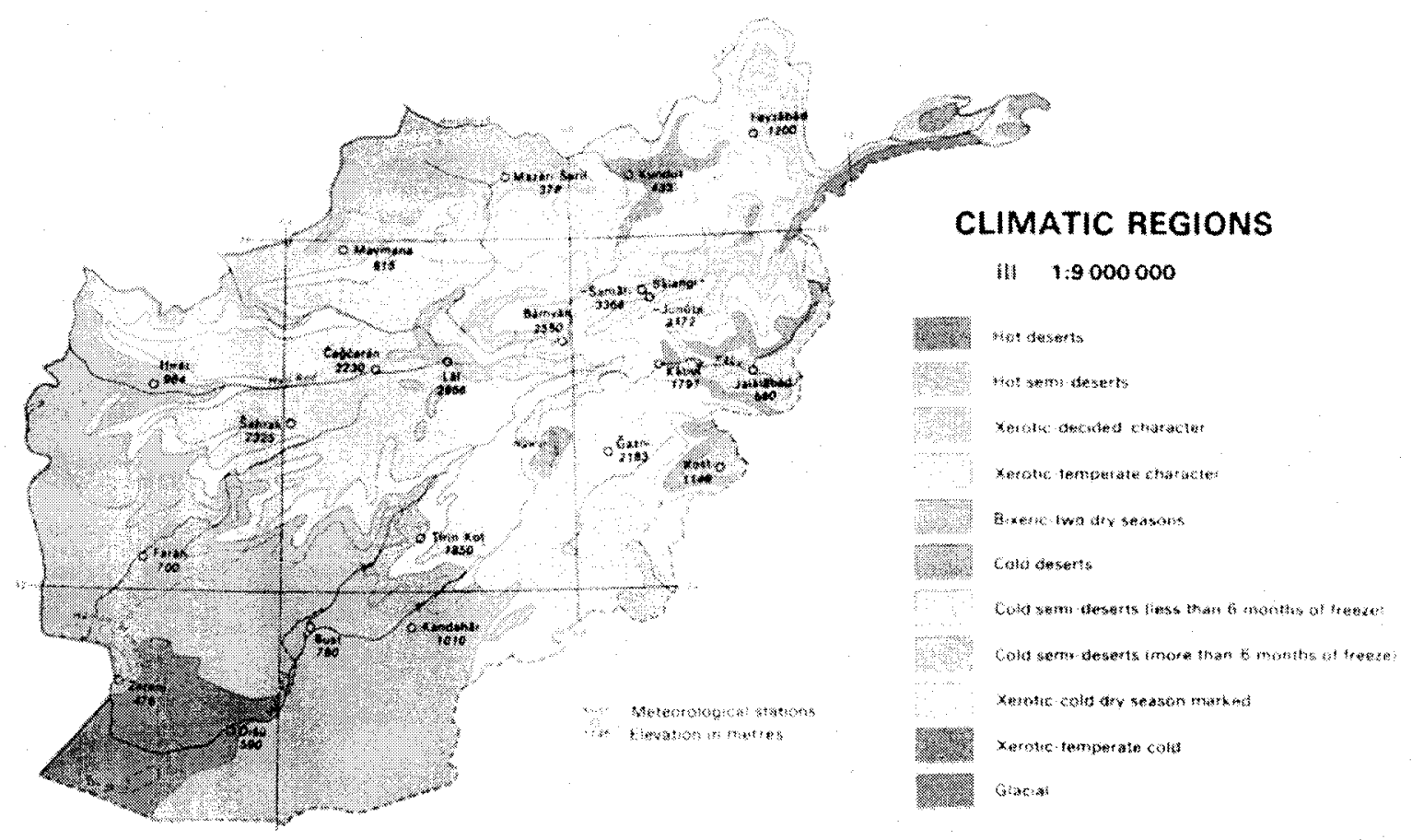




\section{Appendix 7. Soils of Afghanistan (from Sayer and van der Zon, 1981).}

1. Mountain slopes are lithosols. These are shallow, poor soils with little potential for agriculture. They are subject to wind and water erosion. They should be protected by closed vegetation.

2. Lower mountain slopes have shallow regosols or gravelly yermosols with low moisture-holding capacity. They are unsuitable for agriculture and have suffered heavy erosion caused by overgrazing. The best land use is traditional rotational grazing. The loess soils, developed on aeolean deposits, are suitable for irrigated farming.

3. Gently sloping parts of valleys have alluvial deposits or silty yermosols with a well developed horizon of accumulated clay. They suffer a lot of overgrazing. Without irrigation the best land use is rotational grazing on properly managed pastures. With irrigation they are very productive soils for fruit trees and wheat but are very susceptible to erosion.

4. Alluvial soils along the rivers are fertile, calcareous fluvisols. They are the most productive and intensively used soils of Afghanistan and are, with a sufficient water supply, excellent for agriculture.

5. Steppe areas in the north and west have yermosols associated with some lithosols. In the north they include some regosols. They are bare or support scanty vegetation. The best land use is rotational grazing.

6. Lower valleys of the Helmand and Farahrud rivers have playas with clayey soils with a high salt content (solonchaks), formed by evaporation of runoff water coming from the higher areas. They are poor, saline areas, bare or with halophytic vegetation. They are only suitable for low intensity grazing.

7. Desert areas of Registan, to the SE of Mazar-i-Sharif and in the extreme north, have sandy soils (arenosols) associated with regosols. They have a low moisture and nutrient holding capacity and are subject to considerable erosion. Rotational grazing with use adjusted to the carrying capacity can improve productivity.

8. Lower Kabul river and the area north of Mazar-i-Sharif have very dry and sandy soils (xerosols) normally used for poor crops of barley and wheat followed by a year fallow with grazing. Without irrigation crop production is very unreliable.

9. Higher Hindu Rush and the Pamirs have mainly lithosols with little developed deeper soils on the low parts of slopes, on old river terraces and in lacustrine and loess deposits.

The soils of the lower-lying parts of Afghanistan are an association of shallow, stony soils (lithosols, regosols and yermosols), derived from tertiary limestones, marl, calcareous sandstone and shales and characterized by a very low rainfall. Poorly developed soils (cambisols) predominate in mountainous areas. 
Appendix 8.. Vegetation types of Afghanistan (source Sayer and van der Zon, 1981).

\section{Desert vegetation}

The deserts of northern and southern (Registan) A fghanistan contain active sand dune areas and dunes fixed by an-open vegetation. The vegetation is scarcely modified by man. The main plants are Haloxylon porsicum. (alligonum spp and perennial Aristida spp. In lower lying saline areas, Chenopodiaceae are dominant and in the saltplains of Seistan the very open vegetation is characterized by Haloxylon salicornicumn. Salsola spp, Ephedra scoparia, Tamarix spp etc.

\section{Steppe vegetation}

The steppes are the most important grazing areas of the nomads. The low lying steppes in the west and south are dominated by an open vegetation of Artemisia herba-alba and other Artemisia species, Zygophyllum spp, Acantholimon spp, Acanthophyllum spp, Atriplex spp. Alhagi canclorum. Cousinia spp, etc. Along dry riverbeds there are thomy belts of Stocksia brahuica, Amygdalis communis and Convolvulus spinosus. The floral composition is very variable and depends on humidity, length of winter, sand composition. wind force and grazing pressure. More humid places have denser vegetation with a richer species composition. In areas west of Herat with cold winters, Artemisia spp and Ferula spp (Apiaceae) dominate along with geophytes like Iris songarica and Allimm spp.

The northern loess zone supports a grass steppe dominated by Poa bulbosa or Carex pachystylis with Bromus spp, Agropyron spp, Festuca spp, etc. Herbaceous bulbs such as Anemone, Gagea, Tulipa, Iris and Muscari are the first flowering plants in the spring. Shrubs are completely absent. In the spring the ground cover is $30-90 \%$, but most of the plants die back from lack of water in the summer.

In the higher mountains there are areas of semi desert. Around Bamyan they are dominated by Salsola spp. High level steppes benefit from a higher precipitation as well as lower evaporation. Overgrazing generally favours the less palatable Artemisia scrubs and annuals at the cost of the palatable perennials. In dry years when the annuals do not germinate. heavy mortality of domestic animals occurs.

\section{Riverbeds and lakes}

The original forests of the major river valleys have been replaced by irrigated croplands. Tugai vegetation is found in regularly flooded areas. This is dominated by Tamarix spp. willows (Salix spp) and reeds (Phragmites cuistralis) and, depending on the frequency of inundation. species such as Populus spp, Myricaria spp, Berberis spp, Crataegus spp and Hippophaea spp. Herbaceous plants are well represented.

Along the river beds on well drained areas with deep soils, many of the wild ancestors of cultivated fruit trees occur. These include the apple (Pomus spp). pear (Pyrus spp) and almond (Amygdalis spp). Fraxinus spp, Acer spp and Plantamus spp also occur.

Hardly any information is available on the vegetation of the lakes but Hamun-i-Puzak and Kole Hashmat Khan are covered with reeds (Phragmites australis). The only higher plant in the Ab-i-Estada lake is the pondweed (Rrppicalcaririmin) and some Characeae occur in Dashte Nawar. 


\section{Amygdalis scrublands}

Amygdalis scrublands are intermediate between the steppes of the south and west and the woodlands of the Hindu-Kush. These areas are important for winter pasture. An Anygdalis brahrica community is found between 1,000 and $2.000 \mathrm{~m}$ altitude in the dry valleys of the east.

\section{Pistacia and Juniperus woodland}

On the higher slopes of the Hindu-Kush open Pistacia woodlands replace the Amygdalis community. These woodlands are heavily used and badly degraded. The southern slopes of the Hindu Kush are characterized by 4-6 $\mathrm{m}$ high Pistacia cillantica and are rich in herbs like Gagea. Anemone and Allium spp. Pistacia khinjuk and ('ecis griffithii are found in the Kabul/ Logar valley. Above this zone, between 2,000 and $3.000 \mathrm{~m}$ and in areas with more than $400 \mathrm{~mm}$ of precipitation a $2.5-6 \mathrm{~m}$ high Amygdalis community is dominant; many scrub species and geophytes such as Eremurus, Corydalis, Gagea, Tulipa, Allizm spp also occur.

To the north of the Hindu-Kush on the extensive loess plains between 600 and $1.600 \mathrm{~m}$ woodlands of Pistacia vera with some Amygdalis bueharica and in the northeast Cercis griffithii are characteristic. The upper part of the forest belt on the northern slopes of the Hindu Rush is formed by an open mixed woodland dominated by . Imiperus excelsa. The Piatacia vera and Juniperus excelsa woodlands are heavily exploited for charcoal production.

\section{Arid sub-tropical woodland}

Perennial grasses and thorny evergreen shrubs and small trees predominate in the lower Kabul Valley, which experiences hot summers and moderate winters. Heavy grazing and fuelwood collection have reduced the shrubs and led to an increase of annuals. A Zizyphus mummularia community occupies the lower regions (up to $750 \mathrm{~m}$ ). This is replaced at higher levels with a Salvia-Pistacia community. In the dry higher valleys Acacia modesta penetrates the vegetation. Between 700 and $1300 \mathrm{~m}$ there is sometimes a $25 \mathrm{~m}$ high Reptonia buxifolia and Plea ferruginea woodland which is heavily utilized for fodder and as pasture land.

\section{Himalayan deciduous forest}

Between 1,200 and 2,000 $\mathrm{m}$ the oak Quercus baloot dominates a forest which is up to 15 $\mathrm{m}$ high: it has a rich undergrowth and several tree species including almonds (Amygdalis: kuramica)and pistachios ( $P$. khinjuk). $1 \mathrm{t}$ is heavily utilized for fodder. fruits and fuelwood and large parts have been destroyed to provide fuel for Kabul and Kandahar. The Quercus baloot forest in the Pansjir valley northeast of Kabul forms the westernmost extension of the Himalayan forest belt. In very humid places with high summer rainfall $Q$. baloot is replaced by $Q$. dilatata and between $2.400 \mathrm{~m}$ and $2,900 \mathrm{~m}$ by Q. semecarpifolia associated with Juglans regia. Acer turkestanieum and Pyrus pashia.

\section{Temperate coniferous forests of east Afghanistan}

The forest belt between 2.200 and $2.500 \mathrm{~m}$ is a 5-12 $\mathrm{m}$ high Pinus gerardiana woodland with local stands of Betula. A thorny Cotoneaster-Sophora-Rosa scrubland colonizes the areas after the pine has been felled. Between 2.500 and 3,100 $\mathrm{m} \mathrm{Cedrus} \mathrm{deodora} \mathrm{forest} \mathrm{is} \mathrm{found.}$ Depending on soil and humidity the cedars may be up to $50 \mathrm{~m}$ high and form a very dense forest. Large parts of the Cedrus forest have been exploited and replaced by a stable Artemisia community. Logging has now reached even the western parts of Nuristan. 
In the humid areas the upper belt of the forest. up to an altitude of $3.300 \mathrm{~m}$, is formed by a 20-25 m high Picea smithiana - Ahies webbiana forest and in the dry areas by a $10 \mathrm{~m}$ high .Juniperus seravschanica- J.semiglobosa woodland. However most areas have been cut for fuelwood and mature stands are rare. The herbaceous ground cover, especially along the streams. is heavily overgrazed.

\section{Subalpine vegetation}

In areas in the east with summer rains a dense $0.5-1 \mathrm{~m}$ high vegetation of Jumiperus squamata, Rosa spp, Ribes spp and Rhododendron spp develops above $3300 \mathrm{~m}$. On deep soils. Salix spp may dominate this community. In the Hindu-Kush, a Juniperus nana community with many thorny dwarf shrubs occurs. Between 3,600 and 4,000 $\mathrm{m}$ in the central and northern HinduKush, there is a cushion scrubland with species of Acantholimon, Artemisia, Astragalus, Cousinia, Ephedra and Onobrychis as sub-dominants. Many endemics occur in this area.

\section{Alpine and nivale vegetation}

The alpine vegetation of the Hindu-Kush is open and poor in species. That of the Pamirs is denser with a greater variety of herbs. Usually, the alpine meadows, dominated by grasses and a variety of herbs, are heavily utilized during two months as summer pastures by the nomads. In the Pamirs, the boundary with the nivale zone is $4.900 \mathrm{~m}$ on the northern exposed slopes and 5 300-5 $400 \mathrm{~m}$ on the southern exposed slopes. The higher peaks and ridges are dominated by alpine heaths (Ericaceae) and low frost resistant herbaceous and wood vegetation. The highest record of a vascular plant in Afghanistan is the beautiful Primula macrophylla in the central Hindu-Kush at $5,450 \mathrm{~m}$. No seed plants occur in the nivale zone. Some ferns and mosses occur up to $5,630 \mathrm{~m}$ in the Issik Valley in the Pamirs.

Sayer, J.A. and A.P.M. van der Zon. 1981. Afghanistan: National parks and wildlife managenent. A contribution to a conservation strategy. Volume I. FO: DP/AFG/78/007. Technical Report, Vol. I. 


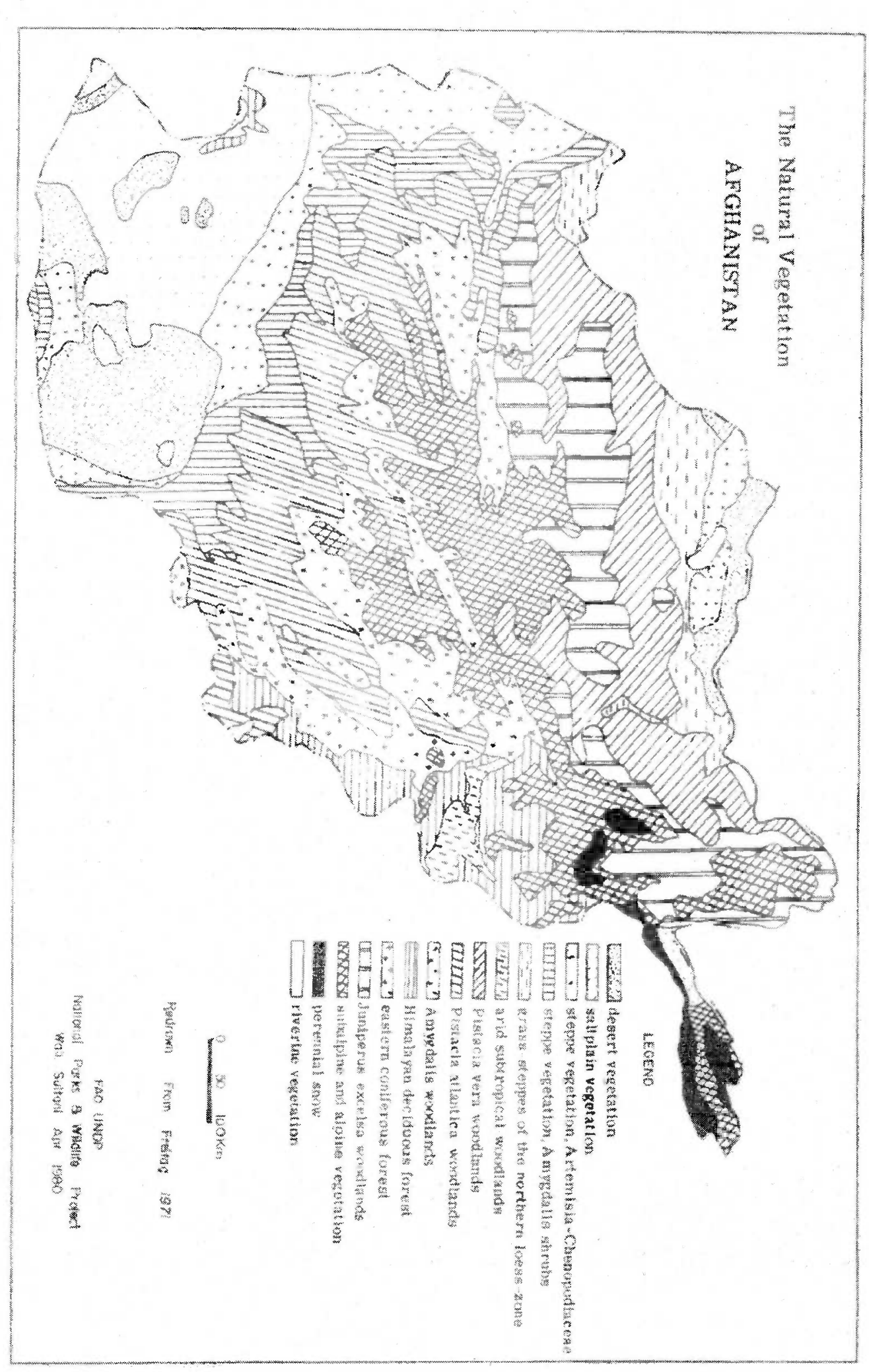

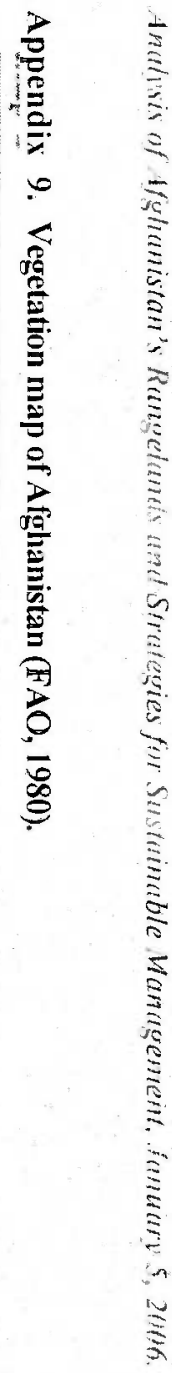




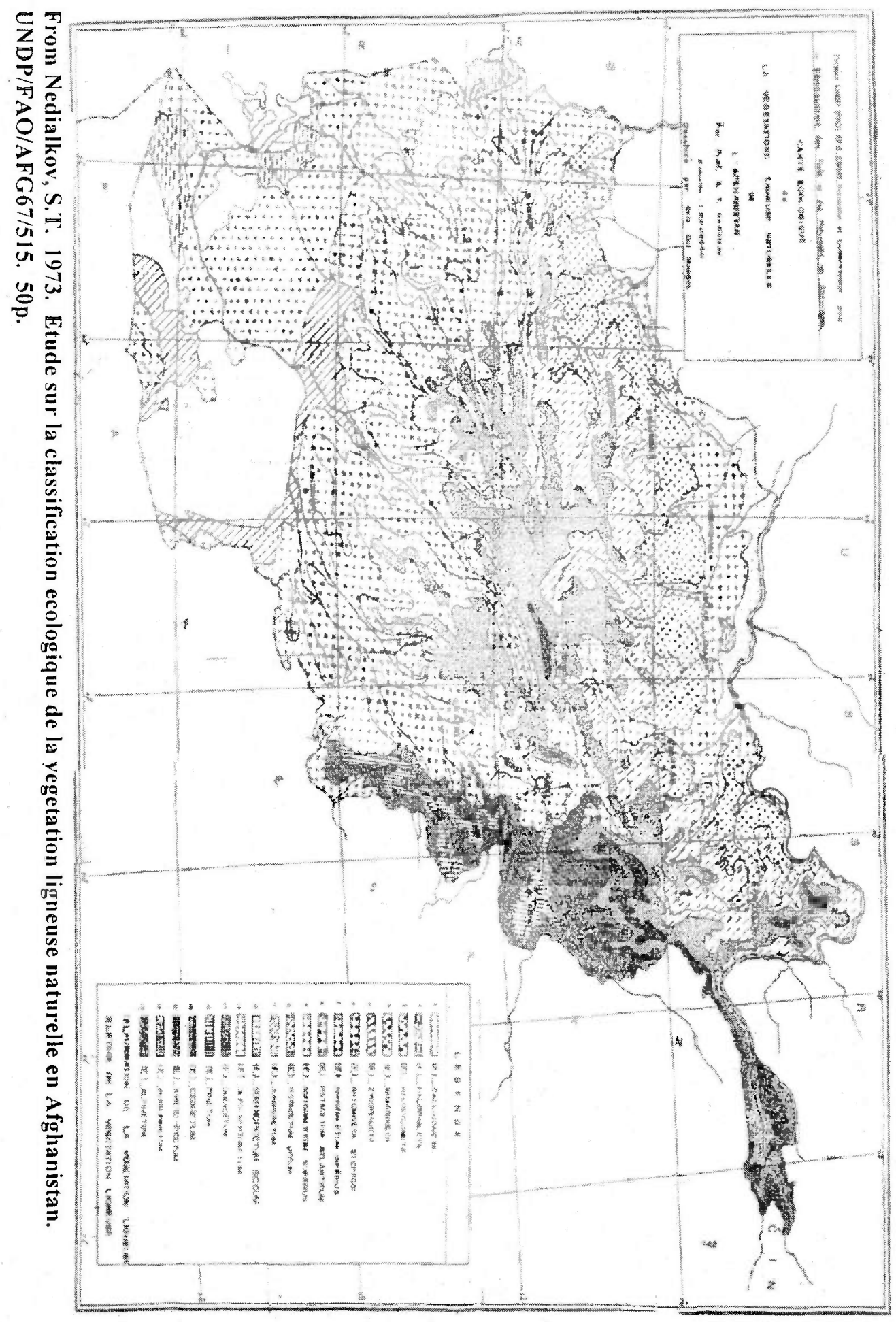

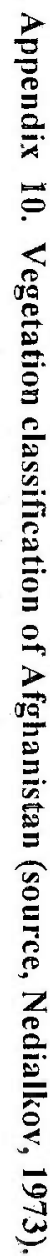




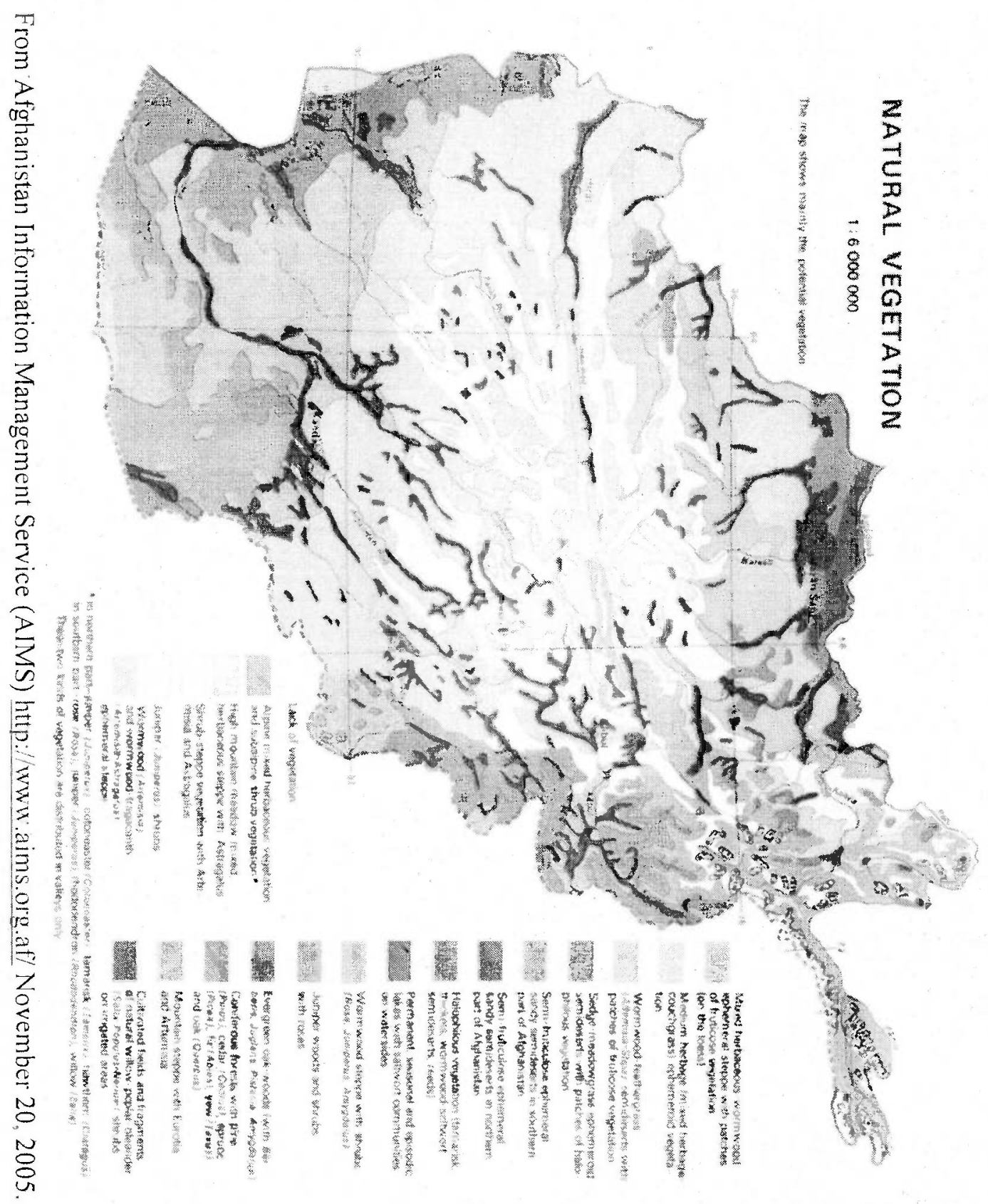

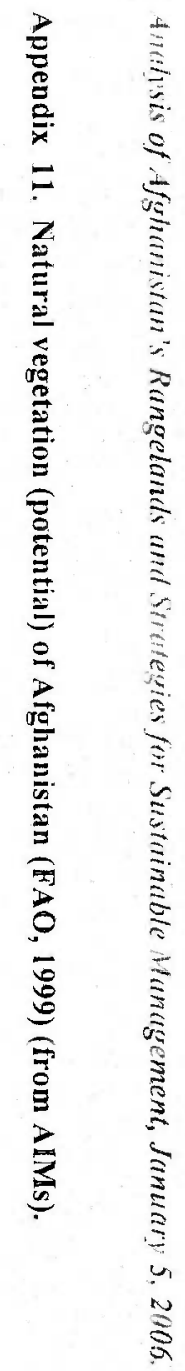




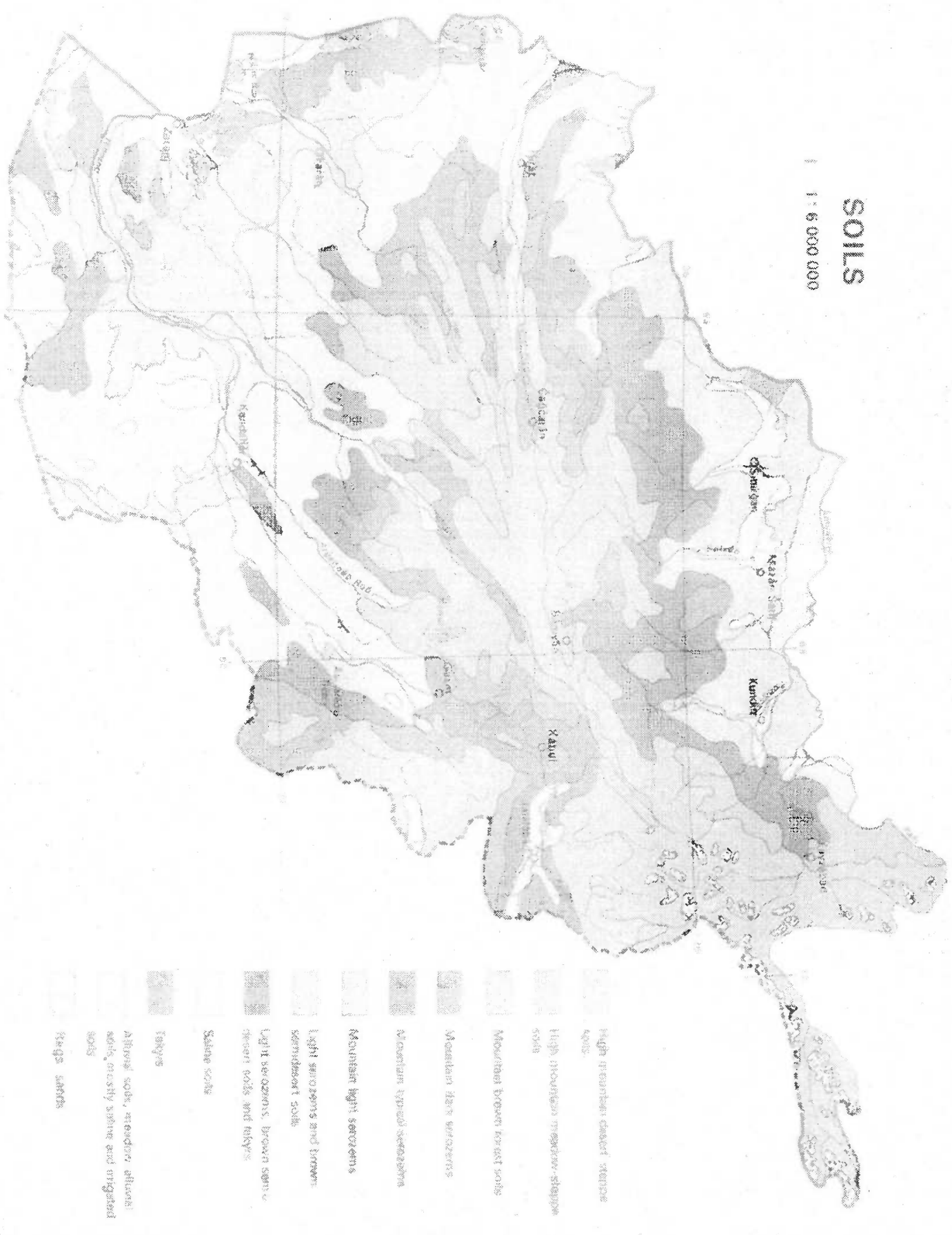

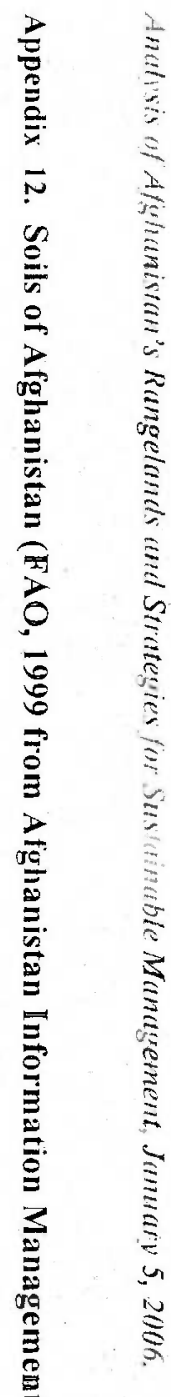


Appendix 13. Forage Resources for Ghazni and Zaboul (from Casady, G.M. nd.).

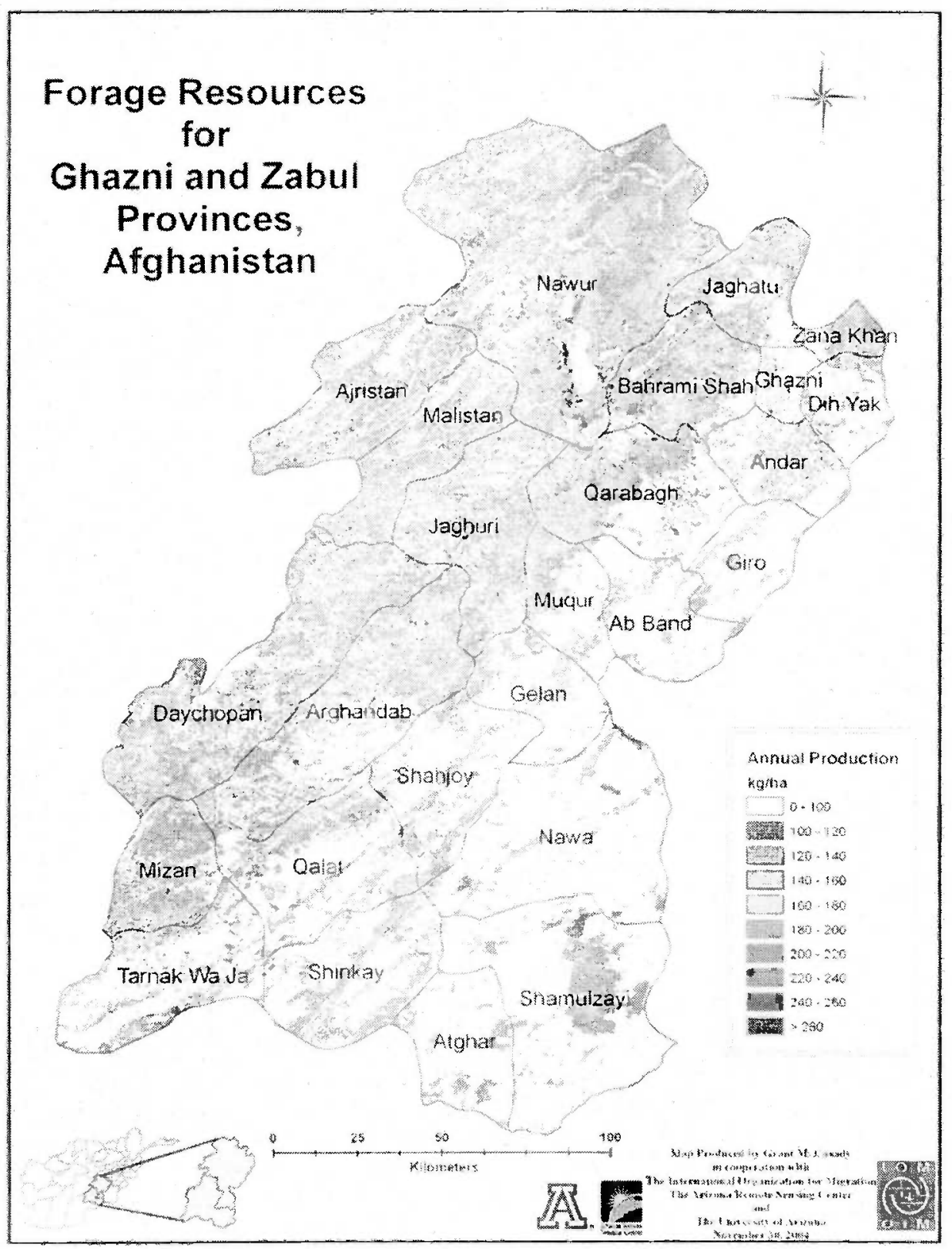

Casady, G.M. nd.. Rangeland assessment of Ghazni and Zabul Provinces. Afghanistan. Report for the International Organization for Migration, Kabul, Afghanistan). 
Appendix 14. Mechanisms to strengthen pastoralist's livelihoods and mechanisms for support of alternative livelihoods (modified from Weijer, 2005).

I. POTENTIAL MECHANISMS TO STRENGTHEN THE PASTORALIST WAY OF LIFE.

A. INSTITUTIONAL STRENGTHENING

1. Strengthen the Ministry of Frontiers and Tribal Affairs for mainstreaming pastoralists' interests.

2. Development of the capacity of the national and provincial Kuchi shuras

B. RANGELAND

1. Technical assessment of the status of the rangeland and potential for rehabilitation

2. Negotiation of access to the resources (rangeland and water).

3. Pasture Monitoring System, linked to a 'Drought Management Strategy'.

4. Advocate for legal framework at all government levels for community resource management.

5. Implement a pilot program for Community based Natural Resource Management.

6. Support on-going Registan work.

C. ANIMAL HEALTH

1. Improve linkages with existing veterinary services/extension through training of Paravets and BVWs and through the establishment of mobile or fixed Veterinary Field Units.

2. Promote establishment of fixed or mobile VFUs in remote pastoral areas.

3. Improve the inclusion of pastoralists in Disease Control and Prevention

D. ANIMAL PRODUCTION AND HUSBANDRY

1. Credit facilities / storage facilities for livestock fodder.

2. Extend extension services to pastoralists

3. Increase livestock feed availability through increased growing of fodder and use of by-products.

4. Identify supplement sources locally produced and available.

5. Promote the fattening of male lambs

E. MACRO-ECONOMIC REGENERATION

1. Initiate feasibility studies/market assessments for livestock and value added livestock products.

2. Improve quality of livestock products (milk, meat, fiber) through extension (quality standards).

3. Encourage private sector investment in the livestock and livestock products industry.

\section{POTENTIAL MECHANISMS TO SUPPORT THE ESTABLISHMENT OF A SUBSTITUTE LIVELIHOOD}

A. Inclusion of the pastoralists as a special focus group in the National Skills development program of the Ministry of Labour and social affairs.

B. Employment Centres for (former) pastoralists.

C. Financial services for (former) pastoralists.

D. Advocate for increased land security for (former) pastoralists in the Land Commission.

E. Promote the development of large-scale irrigation schemes to increase agricultural land.

F. Conduct a pilot project on Joint Natural Resource Management to solve local land insecurity issues.

G. Promote small-scale poultry and rabbit production. 


\section{Appendix 15. The Development of an Integrated Resource Marnagement Plan.}

The following sections describe the resource management planning process in greater detail and discuss needs (training and institutional development) for development of these plans. Although the plan is described in an order it should be stressed that different parts of the planning process are ongoing and should not be considered as sequential. In order to have more efficient planning a geographic information system should be utilized to store and analyze data and remote sensed information (satellite images or air photography) should be incorporated into the planning process.

\section{Development of an Updated Inventory of Resources}

There are a number of steps in developing a successful grazing management plan, but generally the first step is an inventory of resources and conditions. The inventory includes an ecological and social/economic setting, soils, vegetation, habitat or ecological types, water sources, range condition or health (including noxious or poisonous plants), forage production, hay or fodder production, livestock numbers. grazing patterns, and facilities. The intensity of the inventory is based on resource values. objectives of land use and the institutional framework for collecting the information. Criteria for development of ecological sites and for determining/measuring degradation are needed, but may have to be general or simplified as planning must be initiated.

\section{Baseline Information}

Satellite imagery or aerial photographs are needed for base maps. This information should be combined with a geographic information system (GIS) for easier analysis and demonstration. The process for obtaining remote sensed data is to obtain a relatively cloud free image and process the data using image analysis software. Different band combinations are used to illustrate different attributes of the data (i.e., color composites, color infrared). A GlS system is used to overlay information and the spatial information can be queried for analysis and demonstration. I believe the development and mapping of ecological response units is critical in developing sound resource/grazing management plans (also see next section). This will require training. additional equipment to collect the data.

\section{Forage Balance/Land Degradation Measures}

Better information on forage production will be necessary to determine a forage balance to examine alternatives for management. The concept of conservative stocking rates in setting carrying capacity (to reduce grazing impacts. ensure wildlife values. and reduce the probability of natural disasters) should be introduced/reviewed in workshops or manuals in a training session.

Methodology for measuring land degradation and the amount or degraded will need to be developed. Land degradation measurements should be included in monitoring measurements and in inventories to provide information on sites that should be considered for relabilitation. Methodology for measuring land degradation will be discussed in the monitoring sections.

\section{Develop Ecological Response Units and Standards}

An ecological response unit ${ }^{16}$ is a site-based system that allows an ecological basis for land use and management. A specific ecological response unit or ccological site is a specific kind of land with physical characteristics that differs from other kinds of land in the ability to produce distinctive kinds and amounts of vegetation and it its response to management. Sites of the same ecological response unit

\footnotetext{
${ }^{16}$ An ecological response unit is a site-based system that allows an ecological basis for land use and management. Sites within an ecological response unit should respond similarly to management.
} 
should respond similarly to management and should have similar standards for management. The Department of Natural Resources in conjunction with research stations should classify areas into ecological response units and develop best management practices (BN:Ps) for ecological response units and desired future condition associated with land use objectives. Monitoring procedures will vary by ecological response unit and should be developed to determine if goals and objectives are being reached. Theory of ecological response units, development of ecological response units, and development of BMPs will require training and research.

\section{Initiate Integrated Resource Management Planning}

With the resource inventory initiated more specific planning areas should be established and management goals/objectives determined. Determining planning areas and developing sound goals and objectives will require coordinated resource management planning. Planning must be done with range users (pastoralists) and not for them. The development of goals and objective for different resource management areas provide an opportunity for the Department of Natural Resources to work with pastoralists and local communities, and/or herding cooperatives ${ }^{17}$. General goals include maintaining or improving the health and productivity of the rangelands (including biodiversity), maintaining or improving economic returns, maintaining or improving livestock productivity, etc. are objectives that the Department of Natural Resources and local communities will agree on. The development of alternatives for achieving these goals will require more precise objectives, especially where goals may conflict. For example, improving economic returns and ensuring protection of a wild species by deferring or excluding livestock grazing.

Mapping out of grazing management units based on goals and objectives should be done with pastoralists or local communities. The grazing lands that will be alternately grazed and rested (deferrech) could be identified. Forage supply of each grazing unit will be balanced with the forage needs of the livestock and watershed values or other resource concerns of the area. Once grazing units have been mapped out, key grazing areas and key plant species can be identified in each unit. A key grazing area is a relatively small portion of a grazing unit selected because of its location, use or grazing value. A properly selected key area may serve as a monitoring point and will reflect grazing use and effects throughout the grazing unit.

The development of a grazing schedule is used to identify the time and duration of grazing use and the frequency and extent of plant use. Deciding when to move livestock should not be based on calendar dates, but should consider plant growth, precipitation, length of grazing period, frequency of grazing, and other management objectives. Scheduled rest periods for plant recovery after grazing are essential. The length and frequency of planned rest periods will determine the amount of grazing use possible without damage to plants. In general, to avoid selective re-grazing of preferred plants, no grazing unit should be grazed for more than half the growing season.

\footnotetext{
${ }^{17}$ Establishment of herder cooperatives or grazing associations provides a number of benefits. For example, grazing association would allow for the sharing marketing information, group marketing, group training/extension, and demonstration of rangeland, pasture, and livestock treatments.
} 


\section{Appendix 16. Resource Systems Analysis Approacl (summary statement).}

Resource systems analysis planning assists people to appreciate the nature, extent, and importance of the resources. A systems approach is an analytical approach or way of looking at a complex problem. A basic characteristic of systems analysis is that it provides a logical examination of objectives and the alternative ways of achieving these objectives for a variety of resources. In other words it is an organized thinking process which arranges information into categories for sequential use in arriving at a decision or solution. Each system consists of a group of items, practices, or measures that should be considered for each resource area. For example, within the planning area items considered for each resource area should be livestock grazing. wildlife, watershed values, tourism (each system or item may have a number of parts).

There are several phases of this analysis procedure that allows for a better understanding of the consequences of actions. These phases are generally listed as (1) the conceptual phase (the problem is defined); (2) the search phase (search to identify relationships and collate data about the relationships within the system); (3) the analytical or evaluation phase (predicting consequences of alternative actions and comparing the resulting consequences); (4) the interpretation or judgmental phase (conclusions are derived from comparisons and a course of action indicated); and (5) the testing or verification phase (conclusions are tested). However, these phases of analysis can occur only after resource data is available and objectives are defined. This type of resource analysis planning system is in a constant state of review and adjustment. Planning should be visualized as a continuing process where new strategies are evolved as changes in uses, economic conditions, etc. occur and has to be done with the people that the planning directly impacts. Many times this type analysis is very qualitative. but may become more quantitative where there are significant issues related to different uses (for example, grazing use in a protected area).

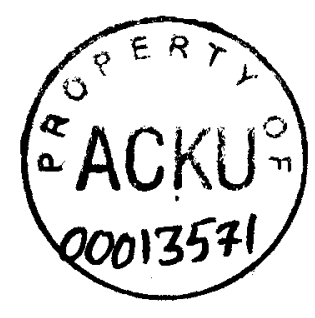

